\title{
ARTICLE
}

\section{Monoclonal antibodies with subnanomolar affinity to tenofovir for monitoring adherence to antiretroviral therapies: from hapten synthesis to prototype development}

Received 00th January 20xx, Accepted 00th January 20xx DOI: $10.1039 / x 0 x \times 00000 x$

\begin{abstract}
Simone Cavalera ${ }^{a}$, Consuelo Agullób, Josep V. Mercader ${ }^{c}$, Fabio Di Nardo ${ }^{a}$, Matteo Chiarello ${ }^{a}$, Laura Anfossi $^{*^{a}}$, Claudio Baggiani ${ }^{a}$, Antonio D'Avolio ${ }^{d}$, Antonio Abad-Somovilla ${ }^{b}$, and Antonio AbadFuentes*c

Approximately 32 million people have died of HIV infection since the beginning of the outbreak, and 38 million are currently infected. Among strategies adopted by The Joint United Nations Programme on HIV/AIDS to end the AIDS world epidemic, the treatment, diagnosis, and viral suppression of the infected subjects are considered crucials for HIV prevention and transmission. Although several antiretroviral drugs (ARV) are successfully used to manage HIV infection, their efficacy strictly relies on the perfect adherence to the therapy, which is seldom achieved. Patient supervision, especially in HIV-endemic, low-resource settings, requires rapid, easy-to-use, and affordable analytical tools, such as enzyme-linked immunosorbent assays (ELISA) and especially lateral flow immunoassays (LFIA). In this work, high-affinity monoclonal antibodies were generated to develop ELISA and LFIA prototypes for monitoring tenofovir (TFV), an ARV drug present in several HIV treatments. TFV was functionalized by inserting a carboxylated C5-linker at the phosphonic group of the molecule, and the synthetic derivative was conjugated to proteins for mice immunization. Through a rigorous screening strategy of hybridoma supernatants, a panel of monoclonal antibodies strongly binding to TFV was raised. Following antibody characterization for affinity and selectivity by competitive ELISA, a LFIA prototype was developed and tentatively applied to determine TFV in simulated urine. The point-of-care test showed ultra-high detectability (the visual limit of detection was $2.5 \mathrm{nM}, 1.4 \mathrm{ng} / \mathrm{mL}$ ), excellent selectivity, and limited proneness to matrix interference, thus potentially making this rapid method a valuable tool for on-site assessment of the patient adherence to ARV therapy.
\end{abstract}

\section{Introduction}

At the gates of the third decade of the 21st century, the Human Immunodeficiency Virus (HIV) still causes hundreds of thousands of deaths worldwide. The number of newly infected people every year (1.7 million in 2018) adds up to the over 38 million HIV positive individuals. ${ }^{1}$ On the other hand, the efficient management of the HIV infection and a Pre-exposure Prophylaxis (PreP) strategy relying onto the so called 'High Activity Anti-Retroviral Treatment (HAART)' approach and have increased the life expectancy up to a non-infected profile. $^{2-4}$ Unfortunately, the efficacy of HAART is weakened

\footnotetext{
a. Department of Chemistry, University of Turin, Turin (TO), Italy

E-mail: laura.anfossi@unito.it; tel.+39-0116705219; fax+39-0116705242.

b. Universitat de València, Departamento de Química Orgánica, Burjassot

(Valencia), Spain

Instituto de Agroquímica y Tecnología de Alimentos (IATA-CSIC), Paterna

(Valencia), Spain

E-mail: aabad@iata.csic.es; tel. +34-963900022; fax+34-963636301.

${ }^{d}$ Unit of Infectious Diseases, University of Torino, Department of Medical Sciences, Torino, Italy

+ Electronic Supplementary Information (ESI) available: Further details about: i) Characterization of TFV Derivatives, ii) MALDI Mass Spectrometry Analysis of Bioconjugates, iii) NMR Spectroscopic Characterization of TFVh and Intermediates. See DOI: $10.1039 / x 0 x x 00000 x$
}

by the low adherence to drug regimens, due to several causes, such as the misunderstanding of complicated regimens, the refusal of the therapy because of psychological and physical side effects, carelessness/inattention, etc. ${ }^{5-8}$ The noncompliance to the therapy bears to intoxications by overdose intake, or to limited efficacy of the therapy and to the development of drug-resistance caused by sub-effective administrations.. ${ }^{9}$ Thus, efficient and rapid diagnostic tools to control the compliance to the HAART are strongly demanded.

Tenofovir (TFV) is a long-established drug used in in the prophylaxis and the treatment of the infections of HIV and Hepatitis C Virus (HCV). ${ }^{10,11}$. It belongs to the class of the nucleotide reverse transcriptase inhibitors (NRTI) and carries out its pharmacological activity by blocking the functionality of the reverse transcriptase, thus inhibiting the production of viral proteins. ${ }^{12}$ It is included, together with other antiretroviral (ARV) drugs, in several commercial coformulations (e.g. with emtricitabine and rilpivirine in Atripla, Descovy, Odefsey, or Eviplera; with elvitegravir in Genvoya; and with bictegravir in Biktevy), TFV is administered as a prodrug, in particular either as the diisoproxil fumarate (TDF) or the alafenamide (TAF) salts. After absorption, the prodrug is hydrolysed to release TFV by the plasmatic esterases, and then phosphorylated into the active form tenofovir diphosphate 
(TDP) in the cell. ${ }^{13}$ The free unphosphorylated fraction of TFV present in the bloodstream is the cause of its toxicity, which is considerably reduced for TAF administered regimens. ${ }^{14,15}$ The drug shows an average $17-\mathrm{h}$ plasmatic half-life, and $70-80 \%$ is excreted in urine as unmodified TFV. The plasmatic and urinary concentrations of TFV have been recently investigated and correlated to the adherence to the HAART by the TARGET study. ${ }^{16-18}$ A large fraction of the HIV-positive patients under HAART treatment are currently administered with a coformulation including one of the two TFV prodrugs. ${ }^{19}$ Hence, detecting TFV represents a versatile tool to monitor the adherence to several combined fixed-dose administrations.

Among methods to measure TFV in biological specimens most are based on liquid chromatography coupled to tandem mass spectrometry (HPLC-MS/MS), which are accurate, precise, and sensitive. ${ }^{20}$ Nevertheless, they require expensive equipment and qualified technicians for operating. In addition, HPLC-MS/MS equipment is usually available only in centralized laboratories. As recommended by the World Health Organization (WHO), the best strategy for assessing therapy adherence is the Point of Care Testing (POCT) approach, which must be affordable, sensitive, selective, user-friendly, rapid and robust, equipment free, and deliverable to the end-user (ASSURED). ${ }^{21}$ Among the technologies meeting these requirements, a prominent role is played by the lateral flow immunoassay (LFIA), also named immunochromatographic strip test (ICST). ${ }^{22}$ A typical LFIA device is portable and allows the direct detection of the target molecule by exploiting the affinity and specificity of the antibody-antigen interaction. ${ }^{23}$

The development of LFIA for the determination of TFV has gained great attention in the last two years. To this aim, specific recognition elements (i.e. anti-TFV antibodies) have been generated. TFV is a small molecule, non-immunogenic by itself, so it requires to be functionalized and covalently attached to a macromolecular carrier to trigger the immune response and generate specific antibodies. However, TFV is an amphiphilic molecule, which complicates the introduction of functional groups for linking it to a carrier. Moreover, some endogenous compounds structurally related to TFV are present in biological samples at very high concentrations, like adenine and its derivatives, adenosine, ADP and ATP. In 2018, Pratt et al. reported the production of rabbit polyclonal antibodies to TFV and their implementation in a LFIA test for measuring the drug in urine. ${ }^{24}$ However, the developed prototype showed some major limitations for practical application, more likely derived from the complex structure of the spacer arm linking TFV to the carrier protein, which eventually resulted in antibodies of moderate affinity to TFV. Almost simultaneously, Gandhi et al. published a paper describing the development of an ELISA to TFV and its application to the determination of this ARV drug in urine. ${ }^{25}$ This work was followed by several others wherein the same research group reported comprehensive clinical studies using this immunoassay to follow patient adherence to the TFVbased HAART, and more recently on the development of a LFIA enabling the determination of clinically relevant TFV levels in urine. $^{26-28}$ While these studies provided compelling evidence of the suitability of immunoanalytical approaches for monitoring the compliance to the ARV therapy, the developed tests showed limited adaptability to more challenging analytical demands, like the analysis of TFV in plasma and saliva samples, or following adherence in patients administered with TAF, which is replacing TDF in ARV coformulations because it shows equivalent efficacy at lower dosage. Moreover, none of these studies discloses the structure of the hapten that was used for the generation of the polyclonal antibodies, nor their binding properties (affinity and specificity) to the analyte.

In TDM by rapid assays, it is commonly acknowledged that monoclonal antibodies are better suited than polyclonal antibodies if a commercial POC test is intended. In this respect, while we were writing this paper, Sevenler et al. reported on the generation of monoclonal antibodies to TFV. ${ }^{29}$ In order to reach this goal, these authors employed a novel hapten containing a carboxylate functional group that was coupled to proteins by carbodiimide-mediated chemistry, so no bulky groups were introduced in the linker. Unexpectedly, these antibodies showed only moderate affinity to TFV, as previously developed antisera. Moreover, the assay exhibited strong interferences by components present in plasma samples, thus precluding the assay of being sensitive enough for its intended use. These results suggest that a good hapten design, although essential, is not sufficient for generating high-affinity antibodies for a particular target.

The aim of this work was the generation of monoclonal antibodies with superior binding properties to TFV than those developed so far and the incorporation of these biomaterials into prototypes of POC tests, like ELISA and LFIA, for rapid and on-site diagnostics of TFV in common biological samples (urine, blood, plasma, and saliva) at clinically relevant concentrations. In order to achieve this goal, a hapten was synthesized, which turned to be very similar to that used by Sevenler at al., and it was coupled to carrier proteins and a reporter enzyme. More importantly, an optimized protocol for the screening of hybridoma supernatants was implemented at very early steps of the antibody selection process. The strategy, consisting of a two-step evaluation procedure that includes a differential and a checkerboard competitive ELISA, has previously demonstrated its efficacy with other analytes for selecting high-affinity and specific binders among a population of clones secreting antibodies with a variety of binding properties. The rationale behind this approach is simple; testing cell cultures for recognition of free TFV in solution at the very beginning of the hybridoma selection process allows ruling out those cell lines that preferentially bind the coating antigen (competing bioconjugate). Accordingly, only monoclonal antibodies with a proved ability of adequately performing in competitive assays are chosen for further cloning, expansion, and in vitro production. The final goal of this work is addressing the lack of a commercial, reliable point-of-care drug monitoring system for TFV through the generation of high-performance immunoreagents. 


\section{Experimental}

\section{Materials and Instruments}

Tenofovir monohydrate was acquired from Tokyo Chemical Industry UK Ltd. The rest of reagents and solvents were acquired from Merck (Darmstadt, Germany) and utilized without purification. Bovine serum albumin (BSA) fraction $V$ was obtained from Roche Applied Science (Mannheim, Germany). Horseradish peroxidase (HRP), ovalbumin (OVA), fetal bovine serum, hybridoma fusion and cloning supplement, and Freund's adjuvants were from Merck (Darmstadt, Germany). HiTrap Sephadex G-25 desalting columns for conjugate purification and HiTrap ${ }^{\mathrm{TM}}$ protein G HP columns for mouse IgG purification were procured from GE Healthcare (Uppsala, Sweden). Immunoassays were carried out with $\operatorname{Costar}^{\circledR}$ 96-well flat-bottom high-binding polystyrene ELISA plates from Corning (Corning, NY, USA). Goat anti-mouse immunoglobulin polyclonal antibody (GAM) was from Jackson ImmunoResearch Laboratories (West Grove, PA, USA). Peroxidase labelled rabbit anti-mouse immunoglobulin polyclonal antibody (RAM-HRP) was from Dako (Glostrup, Denmark). o-Phenylenediamine was obtained from Merck (Darmstadt, Germany). Colloidal Gold (20 nm, OD 10) solution was purchased from BBI Solutions (Crumlin, UK). Backed highbinding nitrocellulose membranes $(25 \mathrm{~mm}$ wide and $15 \mu \mathrm{m}$ pore size) from MDI Advanced Microdevices PVT Ltd. (Ambala Cantt, India), cellulose sample pad (17 $\mathrm{mm}$ wide) from Millipore Corporation (Billerica, MA, USA), cellulose absorbent pad (43 $\mathrm{mm}$ wide) from Ahlstrom-Munksjö (Helsinki, Finland), and $8 \times 30 \mathrm{~cm}$ backing cards from Kenosha (Amstelveen, The Netherlands) were used to build the strips for LFIA.

Hapten density of protein conjugates was determined with a 5800 matrix-assisted laser desorption ionization time-offlight (MALDI-TOF/TOF) mass spectrometry apparatus from $A B$ Sciex (Framingham, MA, USA). An ELx405 washer and a PowerWave HT microplate reader from BioTek Instruments (Winooski, VT, USA) were employed for microplate washing and immunoassay absorbance reading, respectively.

\section{Hapten Synthesis}

The strategy that was followed to synthesize the carboxylated hapten of TFV is schematically summarized in Figure 1 . The following are the specific details used to prepare this hapten and intermediates of its synthesis. The spectroscopic and highresolution mass spectrometric characterization of the synthetized compounds is reported in the Electronic Supplementary Information File.

Synthesis of methyl 5-(()((R)-1-(6-amino-9H-purin-9yl)propan-2-yl)oxy)methyl)(hydroxy)phosphoryl)oxy)

pentanoate (1) and dimethyl 5,5'-(()(1-(6-amino-9H-purin-9yl)propan-2-yl)oxy)methyl)phosphoryl) bis(oxy))(R)dipentanoate (2). $\mathrm{Et}_{3} \mathrm{~N}(200 \mu \mathrm{L}, 1.435 \mathrm{mmol}, 4.4$ equiv) was dropwise added to a stirred suspension of tenofovir monohydrate $(100 \mathrm{mg}, 0.328 \mathrm{mmol}$ ) in $2 \mathrm{~mL}$ of anhydrous $N, N^{\prime}$-dimethylformamide (DMF). After stirring for a few minutes under nitrogen at $\mathrm{rt}$, a clear solution was obtained which was later transformed in a white suspension. Then, methyl 5-bromopentanoate (135.5 mg, $99.4 \mu \mathrm{L}, 0.695 \mathrm{mmol}$, 2.1 equiv) was added and the reaction mixture was heated at $85{ }^{\circ} \mathrm{C}$. Upon reaching this temperature, the initial suspension changed into a slightly brownish solution and then the formation of abundant white precipitate $\left(\mathrm{NEt}_{3} \cdot \mathrm{HBr}\right)$ was observed. After stirring for $24 \mathrm{~h}$, the reaction mixture was cooled down to $\mathrm{rt}$, water $(10 \mathrm{~mL})$ was added, and the mixture was concentrated at reduced pressure; $10 \mathrm{~mL}$ of water were added and again concentrated to dryness. The residue was dissolved in the minimum amount of acetone and adsorbed onto a small amount of silica. The solvent was removed under reduced pressure and the resulting solid was charged onto a silica gel chromatography column and eluted using $\mathrm{CHCl}_{3}$. The eluate, a solution of diester 2 and some $\mathrm{NEt}_{3} \cdot \mathrm{HBr}$ in $\mathrm{CHCl}_{3}$, was transferred to a separatory funnel and washed with water and brine, dried over anhydrous $\mathrm{MgSO}_{4}$, and concentrated under reduced pressure to give pure diester 2 (66 $\mathrm{mg}, 39 \%$ ) as a viscous oil. Further elution of the silica column with $\mathrm{MeOH}$ afforded monoester 1 (59 mg, 45\%) as a white foam, which crystallized from EtOAc-MeOH as white crystals ( $\mathrm{mp}$ 126.5$128.2^{\circ} \mathrm{C}$ ).

Synthesis of 5-(()((R)-1-(6-amino-9H-purin-9-yl)propan-2yl)oxy)methyl)(hydroxy)phosphoryl)oxy) pentanoic acid (TFVh). a) From ester 1. A $1 \mathrm{M} \mathrm{NaOH}(0.2 \mathrm{~mL}, 0.197 \mathrm{mmol}, 4$ equiv) solution was dropwise added to a solution of ester 1 (19.7 mg, $0.049 \mathrm{mmol})$ in $\mathrm{CH}_{3} \mathrm{OH}(0.8 \mathrm{~mL})$ at $\mathrm{rt}$, and the resulting solution was stirred overnight. Then, the reaction mixture was treated with $1 \mathrm{M} \mathrm{HCl}(0.2 \mathrm{~mL}, 4.0$ equiv) to give a clear solution of $\mathrm{pH}$ 6-7 that was concentrated at reduced pressure to dryness. The white solid residue obtained $(32 \mathrm{mg}$ ) was resuspended in $\mathrm{CH}_{3} \mathrm{OH}(1 \mathrm{~mL})$ and the suspension was stirred for $5 \mathrm{~min}$, then filtered with a $0.2 \mu \mathrm{m}$ syringe filter to remove $\mathrm{NaCl}$ and the filtrate was concentrated under vacuum to give TVF $\boldsymbol{h}(18 \mathrm{mg}$, 95\%) as an amorphous solid.

b) From diester 2. A $1 \mathrm{M}$ aqueous solution of $\mathrm{NaOH}(530 \mu \mathrm{L}$, $0.530 \mathrm{mmol}, 5.6$ equiv) and diester 2 (49 $\mathrm{mg}, 0.095 \mathrm{mmol}$ ) in $\mathrm{CH}_{3} \mathrm{OH}(2 \mathrm{~mL})$, prepared in a septum-sealed microwave tube, was irradiated with microwaves (Discover System, CEM Corporation) at $90{ }^{\circ} \mathrm{C}(300 \mathrm{~W})$ for $2 \mathrm{~h}$. The mixture was allowed to cool down to $\mathrm{rt}$, treated with $1 \mathrm{M}$ aqueous $\mathrm{HCl}$, and concentrated at reduced pressure. The white solid residue obtained (78 $\mathrm{mg}$ ) was washed gently with $\mathrm{CHCl}_{3}$ to remove the generated 5-hydroxyvaleric acid, then resuspended in $\mathrm{CH}_{3} \mathrm{OH}$ $(2 \mathrm{~mL})$ and processed as described above for the hydrolysis of 1 to give TVF $\boldsymbol{h}$ as the hydrochloride salt (32.1 mg, 80\%).

\section{Hapten Conjugation to Proteins}

The TFVh was coupled to three carrier proteins. First, the carboxylic functional group of the hapten was activated via formation of the corresponding $\mathrm{N}$-hydroxysuccinimidyl ester (Figure 1), which facilitates its subsequent conjugation to the lysine residues of the proteins through formation of an amide bond.

a) Hapten activation: preparation of the $N$-hydroxysuccinimidyl ester of TFVh (TFVh-NHS).

Anhydrous $\mathrm{Et}_{3} \mathrm{~N}(10 \mu \mathrm{L}, 0.072 \mathrm{mmol}, 2.3$ equiv) was added to a solution of TFVh (13 $\mathrm{mg}, 0.031 \mathrm{mmol}$ ) in anhydrous DMF (310 
$\mu \mathrm{L}$ ) at rt under nitrogen. Then, a solution of $N, N^{\prime}$-disuccinimidyl carbonate (10 mg, $0.039 \mathrm{mmol}, 1.3$ equiv) in DMF (150 $\mu \mathrm{L})$ was added, and the mixture was stirred for $24 \mathrm{~h}$. The resulting reaction mixture, containing the formed TFVh-NHS ester, was used directly for the preparation of the protein-hapten conjugates, as described below. Confirmation of the formation of the active ester of TFV $\boldsymbol{h}$ was obtained from the NMR spectra of the reaction crude obtained by evaporation under reduced pressure of an aliquot of the above reaction mixture. ${ }^{1} \mathrm{H} N M R$ (300 $\mathrm{MHz}$, DMSO- $\mathrm{d}_{6}$ ), only signals corresponding to the $\mathrm{N}$-hydroxysuccinimidyl ester of TFV $\boldsymbol{h}$ are given, $\delta 8.16$ and 8.14 (1H each, each s, H-8 and H-2 Pur), $7.25\left(2 \mathrm{H}, \mathrm{s}, \mathrm{NH}_{2}\right), 4.25(1 \mathrm{H}$, $\left.\mathrm{dd}, J=14.4,3.5, \mathrm{H}_{\mathrm{a}}-1^{\prime \prime}\right), 4.15\left(1 \mathrm{H}, \mathrm{dd}, J=14.4,6.0 \mathrm{~Hz}, \mathrm{H}_{\mathrm{b}}-1^{\prime \prime}\right)$, $3.88\left(1 \mathrm{H}, \mathrm{m}, \mathrm{H}-2^{\prime \prime}\right), 3.75-3.40\left(4 \mathrm{H}, \mathrm{m}, \mathrm{H}_{2}-5, \mathrm{H}_{2}-1^{\prime}\right), 2.80(4 \mathrm{H}, \mathrm{s}$, $\left.\mathrm{COCH}_{2} \mathrm{CH}_{2} \mathrm{CO}\right), 2.66\left(2 \mathrm{H}, \mathrm{t}, J=7.1 \mathrm{~Hz}, \mathrm{H}_{2}-2\right), 1.65-1.40(4 \mathrm{H}, \mathrm{m}$, $\left.\mathrm{H}_{2}-3, \mathrm{H}_{2}-4\right), 1.02\left(3 \mathrm{H}, \mathrm{d}, J=6.1 \mathrm{~Hz}, \mathrm{H}_{3}-3^{\prime \prime}\right)$; ${ }^{31} \mathrm{P} \mathrm{NMR}(121 \mathrm{MHz}$, DMSO-d 6 ) $\delta 15.18$.

\section{b) Preparation of hapten-protein conjugates}

A $50 \mathrm{mM}$ solution of TFVh-NHS in DMF was added dropwise to a protein solution in PB (100 mM phosphate buffer, $\mathrm{pH}$ 7.4) under gentle stirring in amber glass vials. The coupling reactions were carried out during $16 \mathrm{~h}$ at $\mathrm{rt}$, and the DMF concentration in the final mixture never exceeded $20 \%(\mathrm{v} / \mathrm{v})$. As carrier proteins, bovine serum albumin (BSA) was used for immunogen preparation, and ovalbumin (OVA), and horseradish peroxidase (HRP) were employed for coating antigen and enzyme tracer preparation, respectively. The initial hapten-to-protein molar ratios were 40 for BSA, 20 for OVA, and 10 for HRP. Bioconjugates (BSA-TFVh, OVA-TFVh and HRP-TFVh) were purified by gel filtration chromatography with a Sephadex G-25 HiTrap Desalting Column using PB as eluent at $5 \mathrm{~mL} / \mathrm{min}$. The BSA-TFVh conjugate solution was filter sterilized, brought to $1 \mathrm{mg} / \mathrm{mL}$ with sterile $\mathrm{PB}$, and stored frozen at $-20{ }^{\circ} \mathrm{C}$. The OVA-TFV $\boldsymbol{h}$ conjugate solution was diluted with $\mathrm{PB}$ with $0.01 \%(\mathrm{w} / \mathrm{v})$ thimerosal, and stored at -20 ${ }^{\circ} \mathrm{C}$. The HRP-TFV $\boldsymbol{h}$ tracer solution was $1: 1(\mathrm{v} / \mathrm{v})$ diluted with PBS containing $1 \%(\mathrm{w} / \mathrm{v}) \mathrm{BSA}$ and $0.02 \%(\mathrm{w} / \mathrm{v})$ thimerosal, and stored at $4{ }^{\circ} \mathrm{C}$. The obtained hapten-to-protein molar ratio (MR) of each conjugate was determined by Matrix-Assisted Laser Desorption Ionization Time-of-Flight Mass Spectrometry (MALDI-TOF-MS) from water-dialyzed samples of the purified bioconjugates (Figure 2).

\section{Monoclonal Antibody Generation}

Experimental design was approved by the Bioethics Committee of the University of Valencia. Animal manipulation was performed in compliance with the European Directive 2010/63/EU and the Spanish laws and guidelines (RD1201/2005 and 32/2007) concerning the protection of animals used for scientific purposes. A set of six mice was immunized with the BSA-TFVh conjugate by intraperitoneal injections, at 21-day intervals, using complete Freund's adjuvant for the first injection and incomplete Freund's adjuvant for the two subsequent injections. Each animal received $100 \mu \mathrm{g}$ of conjugate in each boost. Four days before cell fusion, a final injection was administered with the same amount of bioconjugate in sterile PBS. Details of the immunization procedure can be found in the Supplementary Information file.

Hybridoma cells were obtained from three independent cell fusions by employing, in each experiment, the spleen cells from two immunized mice. PEG1500 was used as the fusing agent to generate hybridoma cells and they were cultivated following standard protocols. $^{30}$ Hybridoma culture supernatants were assayed twelve days after the cell fusion by a double screening procedure consisting of a differential competitive ELISA (parallel assays were carried out with and without TFV) followed by a checkerboard competitive ELISA using the OVA-TFVh conjugate as coating antigen. The differential test was carried out in microplates coated with 100 $\mu \mathrm{L}$ per well of OVA-TFVh solution at $0.1 \mu \mathrm{g} / \mathrm{mL}$ in coating buffer (50 mM carbonate-bicarbonate buffer, pH 9.6). Each culture supernatant $(40 \mu \mathrm{L})$ was added to two contiguous wells containing $50 \mu \mathrm{L}$ of PBS (11.9 mM phosphate, $\mathrm{pH}$ 7.4, containing $137 \mathrm{mM} \mathrm{NaCl}$ and $2.7 \mathrm{mM} \mathrm{KCl}$ ) or $100 \mathrm{nM} \mathrm{TFV}$ solution in PBS. Those supernatants scored as positive (high signal provided by antibody binding to the coating antigen) and competitive (signal inhibition was higher than $50 \%$ with TFV), were re-evaluated by checkerboard competitive ELISA using microplates coated with $0.01 \mu \mathrm{g} / \mathrm{mL}$ and $0.1 \mu \mathrm{g} / \mathrm{mL}$ solution of OVA-TFVh antigen. Supernatants were four-fold serially diluted in PBS and TFV solutions (10 and $100 \mathrm{nM}$ ) were prepared in PBS. The competitive step was carried out by adding $50 \mu \mathrm{L}$ per well of supernatant dilution in PBS and $50 \mu \mathrm{L}$ per well of TFV solution in PBS or blank PBS solution. Those hybridomas that produced high-affinity mAbs were cloned by limiting dilution using HT medium (hypoxanthine-thymidine solution containing $1 \%(\mathrm{v} / \mathrm{v})$ hybridoma fusion and cloning supplement and $20 \%(\mathrm{v} / \mathrm{v})$ fetal bovine serum). Stable cell clones were expanded in vitro and cryopreserved in liquid nitrogen. Immunoglobulins were purified from late stationaryphase culture supernatants by double ammonium sulfate precipitation and affinity chromatography with protein G. Purified mAbs were stored as ammonium sulfate precipitates at $4{ }^{\circ} \mathrm{C}$.

\section{Indirect Competitive ELISA (icELISA)}

This CELISA format was carried out with immobilized conjugate and indirect antibody detection ${ }^{31}$.

Microplate wells were coated with $100 \mu \mathrm{L}$ per well of OVATFV $\boldsymbol{h}$ solution in coating buffer by overnight incubation at rt. Plates were washed four times with washing solution (140 mM $\mathrm{NaCl}$ with $0.05 \%(\mathrm{v} / \mathrm{v})$ Tween 20 ) after each incubation step. The competitive immunochemical reaction was performed by mixing $50 \mu \mathrm{L}$ per well of TFV solution in PBS with $50 \mu \mathrm{L}$ per well of the anti-TFV mAb solution in PBS-T (PBS containing $0.05 \%$ (v/v) Tween 20). The mixture was incubated for $1 \mathrm{~h}$ at $\mathrm{rt}$ and the plates were washed. The fraction of bound mAb was detected by adding $100 \mu \mathrm{L}$ per well of a $1 / 2000$ dilution in PBS$T$ of peroxidase labelled rabbit anti-mouse immunoglobulin polyclonal antibody (RAM-HRP). The plates were incubated at rt for $1 \mathrm{~h}$, and after washing as before, the signal was generated by adding $100 \mu \mathrm{L}$ per well of $2 \mathrm{mg} / \mathrm{mL} \quad$ phenylenediamine solution in enzyme buffer $(25 \mathrm{mM}$ citrate 
and $62 \mathrm{mM}$ sodium phosphate buffer, $\mathrm{pH} 5.4$, containing $\left.0.012 \%(\mathrm{v} / \mathrm{v}) \mathrm{H}_{2} \mathrm{O}_{2}\right)$. The enzymatic reaction was stopped after $10 \mathrm{~min}$ at $\mathrm{rt}$ by adding $100 \mu \mathrm{L}$ per well of $1 \mathrm{M} \mathrm{H}_{2} \mathrm{SO}_{4}$. The absorbance was immediately read at $492 \mathrm{~nm}$ with a reference wavelength of $650 \mathrm{~nm}$.

\section{Direct Competitive ELISA (dcELISA)}

This CELISA format was performed with immobilized antibody and direct detection using a tracer conjugate ${ }^{31}$.

Microwells were coated by overnight incubation at $4{ }^{\circ} \mathrm{C}$ with $100 \mu \mathrm{L}$ per well of GAM solution at $1 \mu \mathrm{g} / \mathrm{mL}$ in coating buffer. Plates were washed four times with washing solution after each incubation step. Then, $100 \mu \mathrm{L}$ per well of anti-TFV antibody solution in PBS-T was added and incubated for $1 \mathrm{~h}$ at rt. After washing the plates, the competitive reaction was carried out by mixing $50 \mu \mathrm{L}$ per well of TFV solution prepared in PBS and $50 \mu \mathrm{L}$ per well of HRP-TFV $\boldsymbol{h}$ solution prepared in PBS-T. The plates were incubated at rt during $1 \mathrm{~h}$, washed, and the signal was generated as described before for the icELISA.

\section{ELISA Data Analysis}

Calibration curves of TFV were prepared by five-fold serial dilutions in PBS (from 0.0064 to $100 \mathrm{nM}$ ) and a blank was also included. Absorbance values were fitted to a four-parameter logistic equation for standard curves using the SigmaPlot software (Chicago, IL, USA). $A_{\max }$ is the absorbance of the blank, and the TFV concentration affording $50 \%$ reduction of $A_{\max }\left(I C_{50}\right)$ was considered as an estimation of the apparent affinity constant of the antibody.

\section{Monoclonal Antibody Labelling with Gold Nanoparticles}

Conjugation of anti-TFV mAb to gold nanoparticles was conducted by passive adsorption in basic medium, as previously described. ${ }^{32}$ Briefly, $1 \mathrm{~mL}$ of GNP suspension was centrifuged for $10 \mathrm{~min}$ at $7100 \times \mathrm{g}$, and the supernatant was removed and replaced with the same volume of HEPES $20 \mathrm{mM}$, $\mathrm{pH}$ 8.5. Two microlitres of mAb solution $(1 \mathrm{mg} / \mathrm{mL}$ in HEPES buffer) was added to the buffered GNP. The solution was gently stirred and left reacting for $45 \mathrm{~min}$ at rt. Then, $50 \mu \mathrm{L}$ of $5 \%(\mathrm{w} / \mathrm{v})$ BSA solution in HEPES was added and the mixture was incubated for $30 \mathrm{~min}$ at rt. Finally, the GNP-mAb conjugate was recovered by centrifugation (10 $\mathrm{min}$ at $7100 \times \mathrm{g}$ ), washed once with $10 \mathrm{mM}$ Tris- $\mathrm{HCl}$ buffer, $\mathrm{pH} \mathrm{8.5,} \mathrm{and}$ reconstituted in the same buffer supplemented with $0.05 \%$ (v/v) Tween 20. GNPs labeled with the antibodies were stored at $4{ }^{\circ} \mathrm{C}$ until use.

\section{Lateral Flow ImmunoAssay}

LFIA strips in the competitive format ${ }^{33}$ were prepared by using BSA-TFV $\boldsymbol{h}$ and GAM to form the test and control lines, respectively (details on strip production is reported in the ESI). TFV standard solutions were prepared by five-fold serial dilution from a $10 \mathrm{nM}$ solution in the running buffer (Tris- $\mathrm{HCl}$ $10 \mathrm{mM}, \mathrm{pH} 7.4,0.25 \%(\mathrm{v} / \mathrm{v})$ Tween 20 ) from which $75 \mu \mathrm{L}$ was added to a well of a microtiter plate. The wells were supplemented with $25 \mu \mathrm{L}$ of GNP-mAb suspension and incubated for $5 \mathrm{~min}$ at $\mathrm{rt}$. The strips were then dipped into the well. After $10 \mathrm{~min}$, the strips were removed and gently cool-air dried. At this time, strips were scanned, and images were digitally processed to quantify the color intensities of the lines. Signal from lateral flow assays was read using an EPSON Perfection V39 ultra-compact color image scanner from Seiko Epson Corp. (Suwa, Japan). The intensity that was measured at the test line $(T)$ was divided by that of the control line (C) and the T/C intensity ratio was plotted versus the TFV concentration.

\section{LFIA for TFV in Synthetic Urine}

Synthetic urine as a surrogate of the human urine was prepared as reported in the literature. ${ }^{34}$ Fortified urine samples were generated by adding TFV to the synthetic urine to a final concentration of $0.04,0.2,1,5$, and $25 \mathrm{nM}$. Samples were assayed by the LFIA as described above, except that 37.5 $\mu \mathrm{L}$ of fortified urine were diluted with $37.5 \mu \mathrm{L}$ of running buffer and then mixed with $25 \mu \mathrm{L}$ of GNP-mAb suspension.

\section{Results and discussion}

\section{Hapten Synthesis and Bioconjugate Preparation}

Since TFV is a non-immunogenic substance, it needs to be linked to a macromolecular carrier (typically a protein) in order to elicit the immune response. Accordingly, functionalization is required to introduce an activatable chemical group for the subsequent covalent coupling to the protein. Moreover, it is advisable to include a spacer arm so as to keep the target molecule distant from the protein surface, thus promoting the production of antibody binding sites directed towards the analyte rather than to epitopes from the carrier. With this aim, a TFV hapten was synthesized by inserting a five-carbon aliphatic linker at the phosphonic acid moiety of the drug structure. The designed route is quite straightforward and followed a two-step pathway (Figure 1). The first one involved an $\mathrm{O}$-alkylation reaction of the phosphonic acid group of TFV with methyl 5-bromovalerate. This alkylation reaction led to a mixture of the mono- and dialkylated products, $\mathbf{1}$ and $\mathbf{2}$ respectively, which were easily separated by conventional column chromatography.

Figure 1. Synthesis of TFVh and its $\mathrm{N}$-hydroxysuccinimidyl ester (TFVh-NHS). Reagent and conditions: $(\mathrm{a}) \mathrm{Et}_{3} \mathrm{~N}, \mathrm{Br}\left(\mathrm{CH}_{2}\right)_{4} \mathrm{CO}_{2} \mathrm{CH}_{3}, \mathrm{DMF}, 85{ }^{\circ} \mathrm{C}, 24 \mathrm{~h}$; (b) $1 \mathrm{M} \mathrm{NaOH}$, $\mathrm{CH}_{3} \mathrm{OH}, \mathrm{rt}, 16 \mathrm{~h}$; (c) $1 \mathrm{M} \mathrm{NaOH}, \mathrm{CH}_{3} \mathrm{OH}, 90^{\circ} \mathrm{C}, \mathrm{mw}, 2 \mathrm{~h}$; (d) DSC, Et ${ }_{3} \mathrm{~N}, \mathrm{DMF}, \mathrm{rt}, 24 \mathrm{~h}$. 


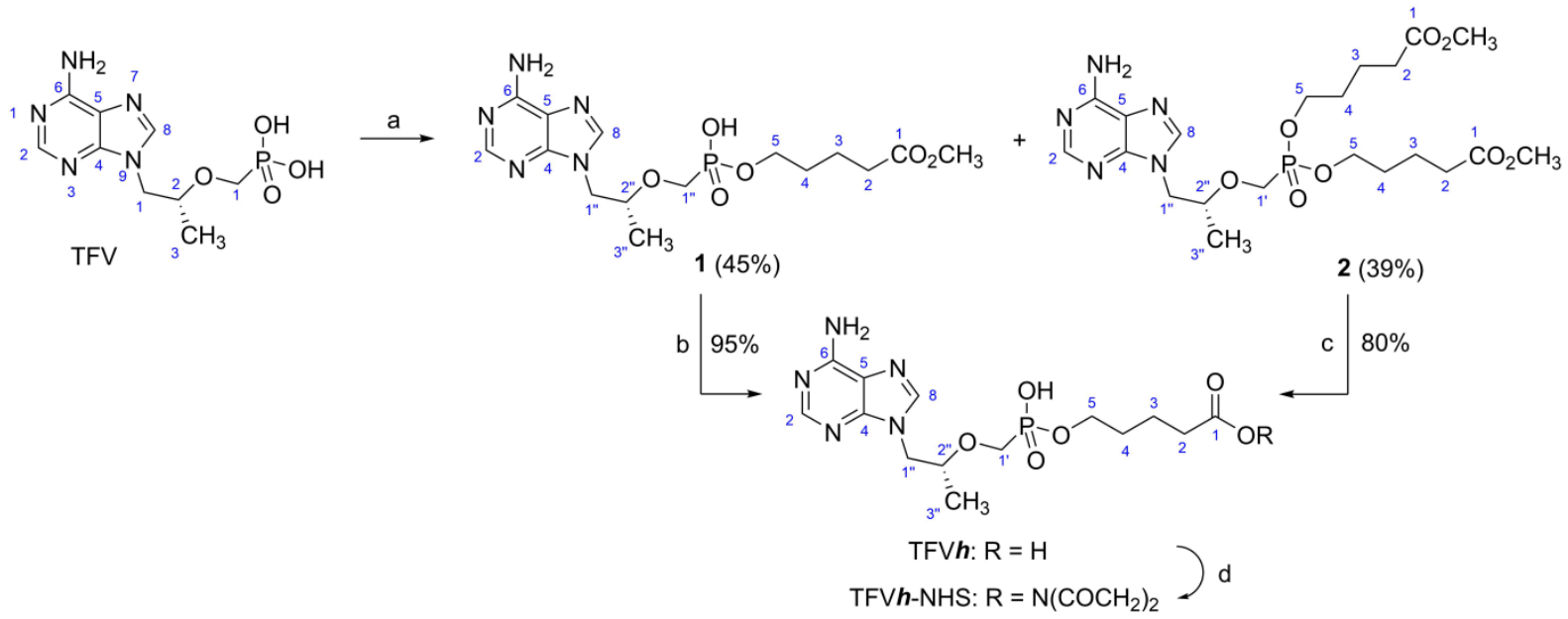

The conversion of each compound into the designed hapten, TVFh, was carried out by hydrolysis in basic medium. With the

methoxycarbonyl group of 1, the hydrolytic reaction leading to the corresponding carboxylic acid took place under very mild temperature conditions, providing TFV $\boldsymbol{h}$ with a very high yield (95\%). However, the transformation of $\mathbf{2}$, which required the hydrolysis of both the carboxylate and the phosphonate groups, needed much more drastic conditions. After testing different reaction procedures, it was found that the hydrolysis could be performed quite efficiently and in a relatively short time using microwaves as the heating source. After acidification, an equimolecular mixture of the hapten and 5-hydroxyvaleric acid was obtained, which were separated with relative ease taking advantage of the much greater solubility of the latter in $\mathrm{CHCl}_{3}$. In summary, TFVh was obtained from TFV with an excellent overall yield of $74 \%$. It is worth mentioning that the hapten (TFV-PO) employed by Sevenler et al. for the generation of anti-TFV mAbs only differs from TFV $\boldsymbol{h}$ in the linker length, even though synthetic details and full characterization data of a carboxylated derivative of TFV are herein reported for the first time.

Figure 2. MALDI-TOF-MS spectra of protein-TFVh bioconjugates (green). Unmodified proteins (blue) were also analyzed for calculation of the hapten densities, and their spectra were also included in the graphs for visual comparison. $\mathrm{MR}_{\mathrm{o}}$ : initial hapten-to-protein molar ratio; MR: hapten-to-protein molar ratio in the final conjugate. The hapten-to-protein molar ratio of OVA conjugate is based on doubly charged protein and conjugate molecular ions. 

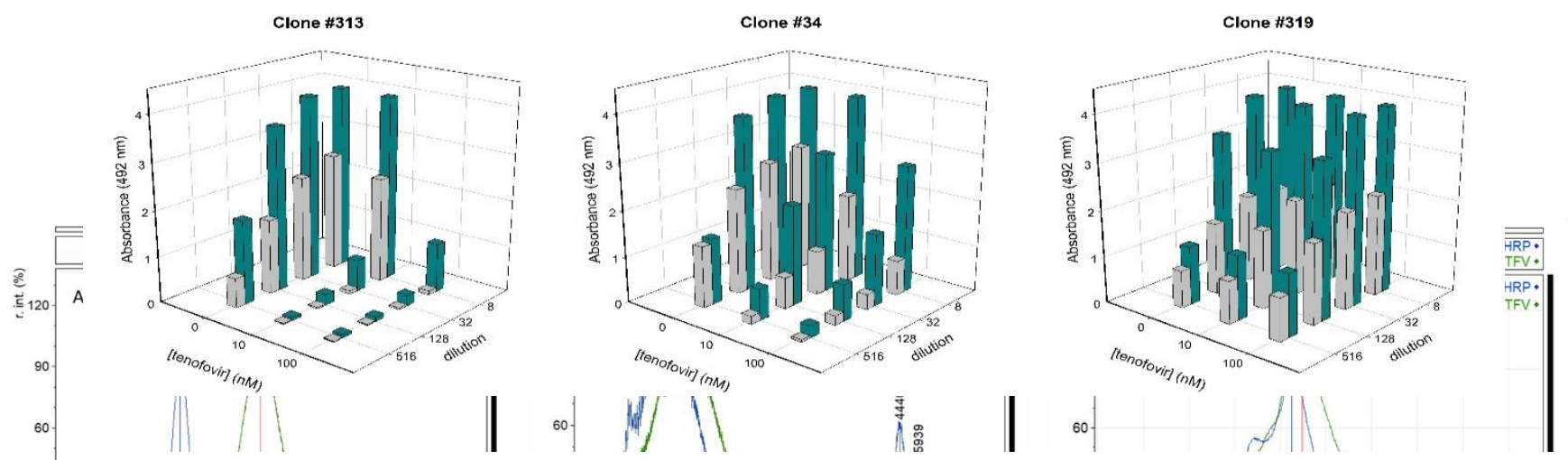

Figure 3. Checkerboard competitive ELISA of post-fusion hybridoma supernatants tested on microwells coated with the conjugate OVA-TFV $\boldsymbol{h}$ at $0.01 \mathrm{ug} / \mathrm{mL}$ (grey bars) and at $0.1 \mathrm{ug} / \mathrm{mL}$ (cyan bars). Each graph represents a different hybridoma producing a monoclonal antibody capable to bind the coating conjugate and showing high-affinity to TFV (clone \#313), medium-affinity to TFV (clone \#34), and no binding to TFV (clone \#319). 600006 These three hybridomas would afford similar results in a conventional non-competitive screening strategy. On the contrary, in our double screening procedure, identification of good and poor TFV binders is straightforward, so clones \#34 and \#319 would not be cloned. BSA

BSA-TFV $71878 \quad 369 \quad 5376 \quad 14.6 \quad 40$

OVA-TFV $\quad 26661 \quad 369 \quad 1465 \quad 7.9 \quad 20$

HRP-TFV $43473 \quad 369$ $230 \quad 0.6 \quad 10$

The terminal carboxylic group of TFVh was converted into the corresponding active NHS ester and covalently linked, by formation of an amide bond, to three different proteins, BSA, OVA, and HRP. The synthesis of TFVh-NHS was carried out using $N, N^{\prime}$-disuccinimidyl carbonate and $\mathrm{Et}_{3} \mathrm{~N}$ in anhydrous DMF (Figure 1). The advantage of using DSC over other NHS-based activating agents is that it does not need dehydration agents and urea derivatives are not produced. The soformed active ester was used directly without prior purification for the preparation of the protein conjugates. Following purification of the bioconjugates by size exclusion chromatography, the hapten-to-protein molar ratios were determined by MALDI-TOF-MS. Hapten densities of $c a .14 .6,5.8$, and 0.6 for BSA-TFV $\boldsymbol{h}$, OVA-TVF $\boldsymbol{h}$, and HRP-TVF $\boldsymbol{h}$ conjugates, respectively, were obtained (Figure 2). Detailed procedures for MALDI-TOF-MS analysis of the prepared bioconjugates are included in the Supplementary Information File.

\section{Generation of Monoclonal Antibodies to TFV}

Three independent cell fusion experiments with B lymphocytes from 6 BSA-TFV $\boldsymbol{h}$ immunized BALB/c mice were carried out. In total, 36 96-well cell culture plates were seeded with the nascent hybridoma cell lines. The mean fusion efficiency (percentage of wells with cell growth 11 days after fusion) was 92\%, with an average of 2.3 clones per well. The hybridoma screening strategy first consisted in a differential competitive ELISA in which each culture supernatant was assayed in two contiguous OVA-TFVh coated microwells $(0.1 \mathrm{ug} / \mathrm{mL})$ with $(100 \mathrm{nM})$ or without TFV in solution. The number of positive wells, i.e., wells showing a clear binding (signal higher than 1.0 ) to the coating antigen was 73 (2.1\%), and 27 of those were also able to strongly recognize free TFV. On the next day, 66 wells were selected for a more comprehensive characterization by checkerboard competitive ELISA. In that assay, supernatants were serially diluted $1 / 8$, $1 / 32,1 / 128,1 / 516$ with PBS-T and tested on microplates coated with the OVA-TFV $\boldsymbol{h}$ bioconjugate at $0.01 \mathrm{and} 0.1 \mathrm{ug} / \mathrm{mL}$, whereas TFV was employed at 10 and $100 \mathrm{nM}$ plus a blank. This strategy allowed us to easily rank hybridomas according to the antibody binding properties with the free drug, thus avoiding wasting resources and time on hybridomas that produce antibodies which recognize the protein-hapten bioconjugate but poorly bind the target analyte (Figure 3).

\section{Characterization of Monoclonal Antibodies by Competitive ELISA}

The output of the implemented double screening process was a collection of 7 hybridoma cell lines, which were cloned by limiting dilution, expanded, and cryopreserved. Following purification by protein $\mathrm{G}$ affinity chromatography from late stationary phase cell cultures, the corresponding mAbs were comprehensively characterized by icELISA using several concentrations of the coating conjugate $(10,30,100$, and $300 \mathrm{ng} / \mathrm{mL})$ and of every antibody $(30,100$, and $300 \mathrm{ng} / \mathrm{mL})$. For each immunoreagent combination, a 7-point standard curve of TFV plus a blank was assayed. Table 1 lists a summary of the obtained results for the $7 \mathrm{mAbs}$ with the optimum immunoreagent combinations, that is, those providing the lowest $I C_{50}$ value together with an $A_{\max }$ value higher than 0.5. Remarkably, all of the mAbs exhibited outstanding affinities to TFV, with $\mathrm{IC}_{50}$ values lower than $1 \mathrm{nM}$. 
Table 1. Checkerboard titration of anti-TFV monoclonal antibodies by icELISA. ${ }^{a}$

\begin{tabular}{lccccc}
\hline $\mathrm{mAb}$ & $\begin{array}{c}{[\mathrm{mAb}]} \\
(\mathrm{ng} / \mathrm{mL})\end{array}$ & $\begin{array}{c}\text { [OVA-TFVh } \\
(\mathrm{ng} / \mathrm{mL})\end{array}$ & $A_{\max }$ & Slope & $\mathrm{IC}_{50}(\mathrm{nM})$ \\
\hline$\# 13$ & 300 & 100 & $1.34 \pm 0.22$ & $1.51 \pm 0.30$ & $0.98 \pm 0.57$ \\
$\# 117$ & 300 & 30 & $1.13 \pm 0.13$ & $1.55 \pm 0.32$ & $0.57 \pm 0.28$ \\
$\# 120$ & 300 & 30 & $0.66 \pm 0.20$ & $1.51 \pm 0.33$ & $0.41 \pm 0.05$ \\
$\# 216$ & 100 & 30 & $1.16 \pm 0.20$ & $1.42 \pm 0.07$ & $0.43 \pm 0.06$ \\
$\# 313$ & 100 & 100 & $0.96 \pm 0.13$ & $1.65 \pm 0.32$ & $0.23 \pm 0.03$ \\
$\# 321$ & 100 & 100 & $1.16 \pm 0.06$ & $1.44 \pm 0.04$ & $0.23 \pm 0.02$ \\
$\# 322$ & 100 & 30 & $1.52 \pm 0.21$ & $1.42 \pm 0.21$ & $0.36 \pm 0.07$
\end{tabular}

${ }^{a}$ Different concentrations of each mAb were tested in plates coated with the OVA-TFV $\boldsymbol{h}$ conjugate at several concentrations. The results shown in this table correspond to the particular combination, for each antibody, resulting in the lowest IC $\mathrm{C}_{50}$ value, provided that an $\mathrm{A}_{\max }$ value higher than 0.5 was obtained. 
a

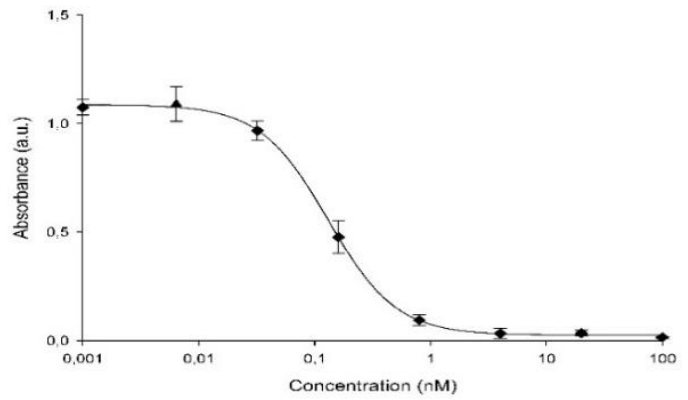

b

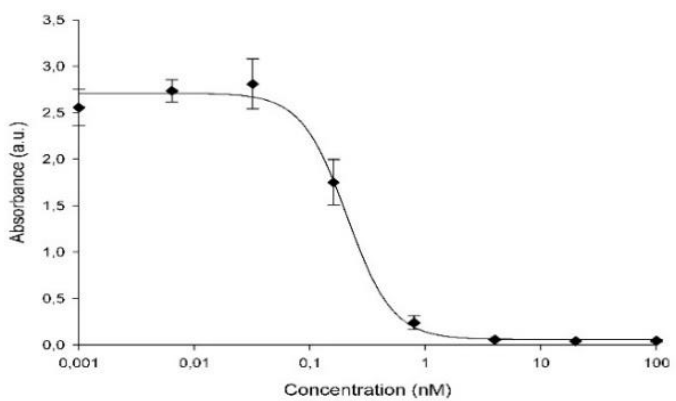

Figure 4. icELISA (a) and dcELISA (b) calibration curves for mAb \#321 with TFV diluted in buffer. The indirect assay was carried out with $100 \mathrm{ng} / \mathrm{mL}$ and $100 \mathrm{ng} / \mathrm{mL}$ of $\mathrm{mAb}$ and coating conjugate, respectively. The direct assay employed $100 \mathrm{ng} / \mathrm{mL}$ of $\mathrm{mAb}$ solution and $300 \mathrm{ng} / \mathrm{mL}$ of tracer conjugate .

It is worthwhile to mention that several antibodies showed apparent affinity constants even lower than $0.3 \mathrm{nM}$, which means IC $_{50}$ values 1000 times lower than those exhibited by previously reported anti-TFV antibodies. These outstanding results are particularly relevant because, as we mentioned before, the hapten that we used for the generation of the mAbs only differs from the one employed by Sevenler et al. in the spacer arm length. ${ }^{29}$ The lowest $\mathrm{IC}_{50}$ value reported by those authors for TFV was $480 \mathrm{nM}$. While we do not have a definite explanation on the reason why our antibodies exhibited higher affinity values, the longer immunization protocol (90 days vs 19 days), which could have allowed for an effective maturation of the immune response, in combination with an optimum screening strategy, are likely at the heart of those results. The performance of the antibody collection was also assessed in the dcELISA format. In this case, the antibody was anchored to the solid support through a capture antibody, and the HRP-TFV $\boldsymbol{h}$ conjugate was used as the tracer for signal generation. While insufficient signals were obtained with most antibodies, the mAb \#321 performed particularly well. Following affinity characterization of the antibody collection, the specificity of the mAbs providing the lowest $I_{50}$ values ( $\mathrm{mAb} \# 313, \# 321$, and \#322) was determined by testing the recognition towards compounds with similar chemical structures and to components of biological fluids that may potentially interfere. Cross-reactivity was measured toward the two TFV prodrugs (TDF and TAF), three analogue compounds eventually found in biological samples (adenine, caffeine, and adenosine triphosphate, ATP), and towards the TFV main metabolite (tenofovir diphosphate, TDP) (Table 2). 


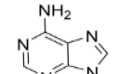

TaÂle 2. Cross-reactivity Pallues (\%) obtained by ${ }^{100}$ ICELISA for the three selected monoclonalöantibodies.

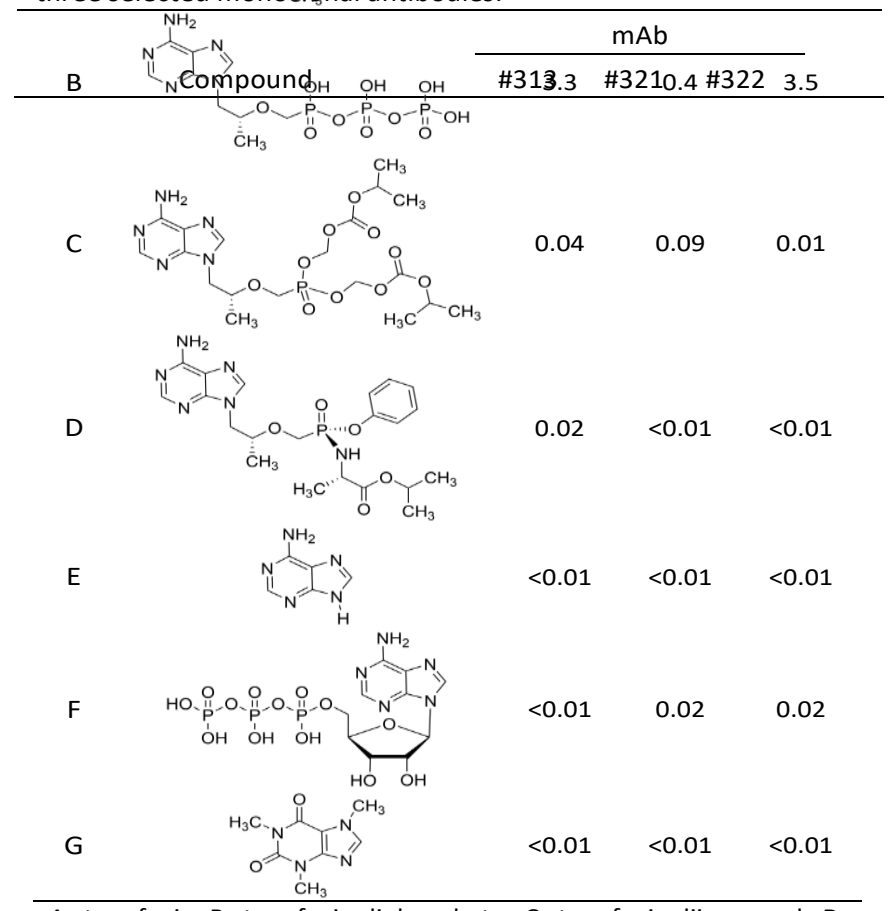

A, tenofovir; B, tenofovir diphosphate; C, tenofovir diisopropyl; D, tenofovir alafenamide; E, adenine; F, adenosine triphosphate; G, caffeine.

Antibodies showed high specificity towards TFV, except for a very limited recognition of the metabolite TDP. Tenofovir is metabolized to TDP - the active form of the drug - into HIV target cells and inhibits the activity of HIV reverse transcriptase. Since TFV is excreted unchanged in urine, TDP is not expected to be found in this biological fluid while it is present in the blood cells. ${ }^{35,36}$ Remarkably, mAb \#321, which showed the highest affinity towards TFV (Figure 4), was also highly specific, whereas mAbs\#313 and \#322 showed a very low but not negligible binding to TDP (CR was around 3\%).

Proneness to matrix interference was evaluated by running TFV standard curves in variable proportions of a simulated urine formulation. ${ }^{34}$ Inhibition curves were plotted and their $A_{\max }$ and $I C_{50}$ values were compared with those obtained with the calibration curve run in buffer. As reported in Figure 5 for mAb \#321, the main parameters of the fitted standard curves remained stable over the studied range of urine concentrations.

Accordingly, a simple $1 / 5$ dilution of the sample in buffer may suffice for minimizing matrix effects, thus proving the ability of the assay to measure TFV at extremely low concentrations. In particular, taking into account the required 5-fold dilution factor, the ELISA based on mAb \#321 would allow analyzing urine samples containing as low as $0.2 \mathrm{nM}$ TFV, i.e., $0.06 \mathrm{ng} / \mathrm{mL}$. TFV urinary levels have been measured by Drain et al. for TDF regimens, and correspond to 4000-14000 $\mathrm{ng} / \mathrm{mL}$ for perfect adherence, $2000-5000 \mathrm{ng} / \mathrm{mL}$ for medium adherence, and $200-600 \mathrm{ng} / \mathrm{mL}$ for low adherence. ${ }^{18}$ Therefore, the detectability of the developed ELISA exceeds by far the lowest TFV levels found in low adherence situations. In fact, it would allow TDM in patients following TAF regimens, wherein the TFV dose is 10 times lower than in TDF regimens. 


\title{
Development of a LFIA exploiting high-affinity mAbs towards TFV
}

As a proof-of-concept to illustrate the potential for point-of-care testing of the herein reported immunoreagents, the three mAbs displaying the highest affinity to TFV were selected as candidates for inclusion in a lateral flow immunoassay. A schematic representation of the LFIA, using GNPs as the colorimetric probe, is shown in Figure 6. Briefly, in the absence of TFV, the GNP-labelled antibodies bind to the test line, resulting in the accumulation of GNPs and the formation of a red line. Instead, the presence of increasing amounts of TFV in the sample progressively inhibit the binding of GNP-labelled antibodies to the test line. Correspondingly, the color of the test line fades until disappearance.

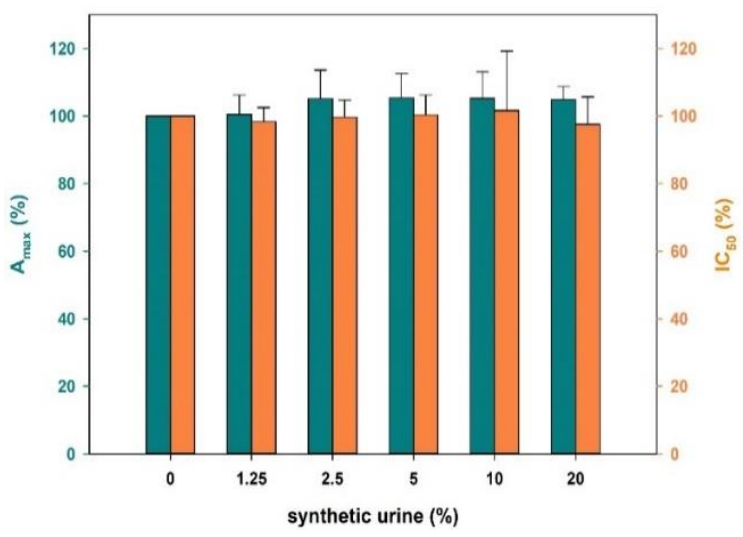

Figure 5. Interference of different proportions of a simulated urine formulation over the $A_{\max }$ and $I C_{50}$ values of the icELISA standard curve based on mAb \#321. Each value represents the mean of three determinations carried out on different days.

\begin{abstract}
Figure 6. Scheme of the LFIA for TFV detection. (a) The antigen (BSA-TFVh) and GAM were spotted onto the capillary membrane to form the test and the control lines, respectively. (b) Strips were dipped in a microplate well containing the anti-TFV antibody labelled with gold nanoparticles (GNP$\mathrm{mAb}$ ) and the sample. In the absence of the target drug, the GNP-mAb bound to BSA-TFVh and to GAM, so it accumulated both at the test and control lines resulting in the appearance of two visible red lines. (c) In the presence of the drug (TFV), the binding to the BSA-TFV $\boldsymbol{h}$ at the test line was inhibited, thus only the control line was made visible.
\end{abstract}

The three mAbs under investigation (\#313, \#321, and \#322) were labeled with GNPs by passive adsorption. ${ }^{37}$ Previously, the appropriate amount of each mAb to be adsorbed onto the GNPs was established by flocculation test. ${ }^{38,39}$ The amounts of antigen to form the test line and of GNP-labelled antibodies were established for each mAb by a checkerboard approach, as those assuring a clearly visible coloring of the test line in the absence of TFV. The immunostrips were tested by applying solutions with TFV serially diluted in the running buffer and in diluted synthetic urine. The urine matrix prevented the gold conjugate flowing through the membrane; however, a $1+1$ dilution with the buffer sufficed to re-establish a rapid and uniform flow. To investigate the matrix effect, synthetic urine was spiked with $2 x$ concentrated TFV standard solution and diluted $1+1$ with the buffer to reach the same nominal concentration of the calibrators prepared in buffer (Figure 7). The LFIA results were observed by the naked eyes and images were photographically captured for quantitative analysis. Color intensities of the test (T) and control (C) lines were measured, and the T/C ratio was plotted versus the TFV concentration to calculate the $\mathrm{IC}_{50}$ parameter. As the LFIA was intended for point-of-care testing application, we also estimated the visual limit of detection (VLOD), which was defined as the TFV concentration that completely inhibited coloring of the test line. 


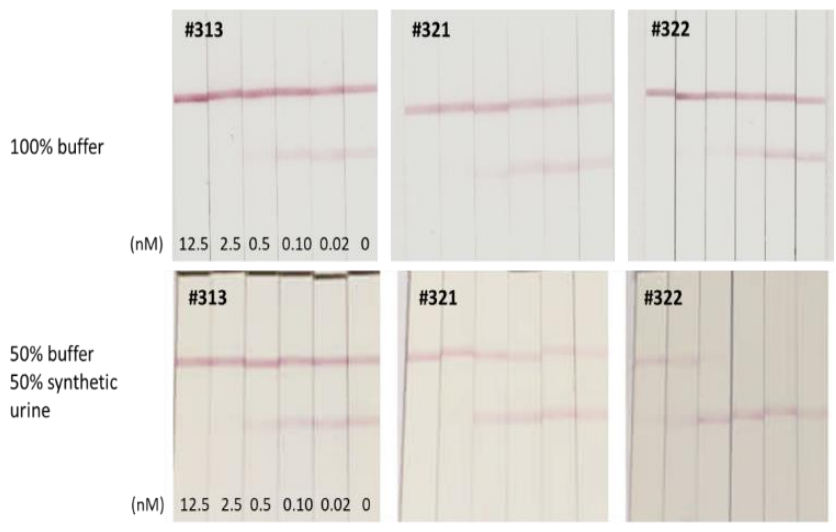

Figure 7. LFIA calibration carried out for TFV (from left to right: $12.5,2.5,0.5,0.1$, $0.02,0 \mathrm{nM})$. The curves made in synthetic urine were prepared $2 x$ concentrated and subsequently diluted $1+1$ with the running buffer to reach the same nominal concentration of TFV as for the curve in the running buffer. Actual urinary TFV levels are obtained by multiplying by two the values in the figure.

The control line largely varied and increased as a function of the increasing TFV amount. This can be explained by the displacement of GNP-mAb from the test line, which resulted in their accumulation at the control line. This phenomenon was observed when TFV was dissolved in the running buffer; however, it seemed more pronounced in the presence of the synthetic urine matrix. The net effect of the increasing coloring of the control line parallel to the decrease of the color at the test line was that the variation of the signal ( $T / C$ ratio) versus TFV concentration was magnified and contributed to the high sensitivity of the LFIA. Therefore, in this case, the control line not only allowed us to reduce strip-to-strip variability as previously observed ${ }^{40}$ but also increased the sensitivity. As reported in Table 3, the three mAbs confirmed high sensitivities with $\mathrm{IC}_{50}$ values below $1 \mathrm{nM}$, both in buffer and in urine. MAb \#322 showed the best performance in terms of IC $\mathrm{C}_{50}$, while $\mathrm{mAb} \# 321$ provided the lowest VLOD, reaching the complete disappearance of the test line color at as low as $2.5 \mathrm{nM}$ of TFV when dissolved in buffer. In general, a slight decrease of sensitivity, measured by the IC $\mathrm{C}_{50}$ and vLOD parameters, was observed for the three systems. Particularly, the signal of the control line was more influenced by the studied matrix, especially for mAb \#322. The robustness of the three mAbs towards ionic strength and $\mathrm{pH}$ was studied by carrying out calibration curves in the ic ELISA format in different media. The amount of the salt and the pH were lowered and increased compared to the reference phosphate buffer $(20 \mathrm{mM}, \mathrm{pH} 7.4$ supplemented with $130 \mathrm{mM}$ of $\mathrm{NaCl})$ used in this work. The amount of salt added was 0 and $230 \mathrm{mM}$ and $\mathrm{pH}$ was lowered to 6.5 and increased to 8.5 . The binding to the antigen, and the sensitivity of the mAbs, as measured by the $A_{\max }$ and $I C_{50}$ values, respectively, were affected differently by the medium (Figure S1). In general, increasing salt amount and pH value lowered the binding to the antigen (Fig. S1a) while the acidic medium had a limited impact. The effect on sensitivity was largely different for the three antibodies (Fig S1b): mAbs \#13 and 322 were largely affected by both pH and salt modification, although in different ways, while mAb \#321 confirmed to be more robust. The vLODs achieved in urine, capitalizing on the high-affinity mAbs herein reported, were in the 2.5-25 nM range, which corresponds to TFV concentrations between $1.4 \mathrm{and} 7.2 \mathrm{ng} / \mathrm{mL}$ in the urine sample. In the work by Gandhi et al., a discrete cut-off value for urinary TFV (1500 ng/ml) was proposed to correctly classify the adherence to therapy in $98 \%$ of the individuals administered with TDF. ${ }^{25}$ The LFIA prototype herein described showed 1000 -fold lower vLOD than required, and 600 times lower than those previously reported ${ }^{24,26}$ Although exceeding current requirements, the low VLOD that was reached fits with the incoming needs of increasing TFV detectability, due to the introduction of the TAF prodrug. In fact, TAF penetrates the blood and hepatic cells better than TDF, and it is administered usually in 10-fold lower amount compared to TDF. ${ }^{41}$ Therefore, point-of-care test intended for checking adherence to regimens including TAF are required to show proportionally reduced limits of detection.

Table 3. Detectability of TFV by the LFIAs including the selected mAbs. The analytical performance of the LFIAs was checked by diluting TFV in the running buffer and in $1+1$ diluted synthetic urine.

\begin{tabular}{ccccc} 
& \multicolumn{2}{c}{$\mathbf{I C}_{\mathbf{5 0}}$ (nM) } & \multicolumn{2}{c}{ VLOD $^{\text {a }}$ (nM) } \\
\hline \multirow{2}{*}{ mAb } & $\begin{array}{c}\text { Running } \\
\text { buffer }\end{array}$ & $\begin{array}{c}\text { Synthetic } \\
\text { urine }\end{array}$ & $\begin{array}{c}\text { Running } \\
\text { buffer }\end{array}$ & $\begin{array}{c}\text { Synthetic } \\
\text { urine }\end{array}$ \\
\hline$\# 313$ & 0.4 & 0.7 & 2.5 & 12.5 \\
$\# 321$ & 0.5 & 0.7 & 2.5 & 2.5 \\
$\# 322$ & 0.3 & $-{ }^{-}$ & 12.5 & $>12.5$ \\
\hline
\end{tabular}

${ }^{a}$ The VLOD was defined as the TFV concentration that caused the complete disappearance of the color at the test line. ${ }^{\mathrm{b}}$ Not determined, since the T/C ratio could not be calculated for the blank sample. 


\section{Conclusions}

In this work, we designed, synthesized, and characterized a new hapten of TFV and generated seven mAbs with ultra-high affinity towards this ARV drug. Compared to other antibodies raised towards TFV, our selection strategy provided bioligands with higher affinity and selectivity properties. ${ }^{29}$ The mAbs were characterized by icELISA and were explored for their implementation in a LFIA-based point-of-care test for TFV detection in urine. The sensitivity showed by the ELISA and LFIA prototypes, exploiting the novel mAbs, was largely above the requirement for assessing adherence to antiretroviral therapy, even considering new co-formulations including the TAF prodrug ${ }^{41}$. This high detectability, which largely exceeds that of previous rapid analytical tests, allows us envisaging the application of these new immunoreagents for the detection of the TFV contents in more challenging biological fluids, where drug concentrations are expected to be lower than in urine (e.g. blood, plasma and saliva).

\section{Conflicts of interest}

There are no conflicts to declare.

\section{Acknowledgements}

This work was supported by the Spanish Ministerio de Economía y Competitividad (AGL2015-64488 and RTI2018-096121) and cofinanced by European Regional Development Funds. Samples of the immunoreagents to TFV herein reported are available upon request from $\mathrm{A}$. Abad-Fuentes.

\section{References}

2020 Fact Sheet available at: https://www.unaids.org/en/resources/fact-sheet (last access 13th of July 2020)

D. J. Jamieson, C. C. King and A. P. Kourtis, Clin. Gynecol. Second Ed., 2015, 24, 360-370.

A. Trickey, M. T. May, J. J. Vehreschild, N. Obel, M. J. Gill, H. M. Crane, C. Boesecke, S. Patterson, S. Grabar, C. Cazanave, M. Cavassini, L. Shepherd, A. d. A. Monforte, A. van Sighem, M. Saag, F. Lampe, V. Hernando, M. Montero, R. Zangerle, A. C. Justice, T. Sterling, S. M. Ingle and J. A. C. Sterne, Lancet HIV, 2017, 4, e349-e356.

F.Diamond, Managed care (Langhorne, Pa.), 2018, 11

W. M. Bezabhe, L. Chalmers, L. R. Bereznicki and G. M. Peterson, Medicine (Baltimore), 2016, 95, 1-9.

J. Kim, E. Lee, B. Park, J. H. Bang and J. Y. Lee, Sci. Rep., 2018, 8, 3133.

T. N. Gengiah, A. Moosa, A. Naidoo and L. E. Mansoor, Int J Clin Pharm, 2014, 36, 70-85.

S. A. lacob, D. G. lacob and G. Jugulete, Front Pharmacol, 2017, 8, 831.

N. A. Bokulich, S. Subramanian, J. J. Faith, D. Gevers, J. I. Gordon, R. Knight, D. A. Mills and J. G. Caporaso, Physiol. Behav., 2017, 176, 139-148.

R. Byrne, I. Carey and K. Agarwal, Therap. Adv. Gastroenterol., 2018, 11, 1-12.

J. S. Orman and C. M. Perry, Drugs, 2008, 68, 1435-1463.

H. B. Fung, E. A. Stone and F. J. Piacenti, Clin. Ther., 2002, 24, 1515-1548.

G. E. Chittick, J. Zong, M. R. Blum, J. J. Sorbel, J. A. Begley, N. Adda and B. P. Kearney, Antimicrob. Agents Chemother., 2006, 50, 1304-1310.

B. Fernandez-Fernandez, A. Montoya-Ferrer, A. B. Sanz, M. D. Sanchez-Niño, M. C. Izquierdo, J. Poveda, V. Sainz-Prestel, N. Ortiz-Martin, A. Parra-Rodriguez, R. Selgas, M. Ruiz-Ortega, J. Egido and A. Ortiz, AIDS Res. Treat., 2011, 2011

H. H. Ng, H. Stock, L. Rausch, D. Bunin, A. Wang, S. Brill, J. Gow, and J. C. Mirsalis, Int J Toxicol., 2015, 34, 4-10.

M. Simiele, C. Carcieri, A. De Nicolò, A. Ariaudo, M. Sciandra, A. Calcagno, S. Bonora, G. Di and A. D. Avolio, J. Pharm. Biomed. Anal., 2015, 114, 8-11.

P. L. Anderson, EClinicalMedicine, 2018, 2-3, 5-6.

T. R. Cressey, O. Siriprakaisil, V. Klinbuayaem, J. Quame-Amaglo, R. W. Kubiak, P. ornsuda Sukrakanchana, K. Than-in-at, J. Baeten, W. Sirirungsi, R. Cressey and P. K. Drain, BMC Infect. Dis., 2017, 17, 1-6.

H. F. Günthard, M. S. Saag, C. A. Benson, C. Del Rio, J. J. Eron, J. E. Gallant, J. F. Hoy, M. J. Mugavero, P. E. Sax, M. A. Thompson, R. T. Gandhi, R. J. Landovitz, D. M. Smith, D. M. Jacobsen and P. A. Volberding, JAMA - J. Am. Med. Assoc., 2016, 316, 191-210.

A. Calcagno, D. Gonzalez de Requena, M. Simiele, A. D'Avolio, M. C. Tettoni, B. Salassa, G. Orofino, C. Bramato, V. Libanore, I. Motta, P. Bigliano, E. Orsucci, G. Di Perri, S. Bonora,AAC, 2013, 57, 1840-1843.

G. Wu and M. H. Zaman, Bull World Health Organ. 2012, 90, 914-920. 
K. H. Ching, Methods Mol Biol, 2015, 1318, 127-37

K. M. Koczula and A. Gallotta, Essays Biochem., 2016, 60, 111-120.

G. W. Pratt, A. Fan, B. Melakeberhan and C. M. Klapperich, Anal. Chim. Acta, 2018, 1017, 34-40.

M. Gandhi, P. Bacchetti, W. C. Rodrigues, M. Spinelli, C. A. Koss, P. K. Drain, J. M. Baeten, N. R. Mugo, K. Ngure, L. Z. Benet, H. Okochi, G. Wang and M. Vincent, EClinicalMedicine, 2018, 2-3, 22-28.

M. Gandhi, G. Wang, R. King, W. C. Rodrigues, M. Vincent, D. V Glidden, T. R. Cressey, P. Bacchetti, M. A. Spinelli, H. Okochi, O. Siriprakaisil, V. Klinbuayaem, N. R. Mugo, K. Ngure, P. K. Drain and J. M. Baeten, AIDS, 2020, 34, $255-260$. M. Gandhi, P. Bacchetti, M. A. Spinelli, H. Okochi, J. M. Baeten, O. Siriprakaisil, V. Klinbuayaem, W. C. Rodrigues, G. Wang, M. Vincent, T. R. Cressey and P. K. Drain, J. Acquir. Immune Defic. Syndr., 2019, 81, 72-77.

M. A. Spinelli, D. V. Glidden, W. C. Rodrigues, G. Wang, M. Vincent, H. Okochi, K. Kuncze, M. Mehrotra, P. Defechereux, S. P. Buchbinder, R. M. Grant and M. Gandhi, AIDS, 2019, 33, 867-872.

D. Sevenler, A. Bardon, M. Fernandez Suarez, L. Marshall, M. Toner, P. K. Drain and R. D. Sandlin, ACS Infect. Dis., 2020, 6, $1635-1642$

J. V. Mercader, C. Suárez-Pantaleón, C. Agulló, A. Abad-Somovilla and A. Abad-Fuentes, J. Agric. Food Chem., 2008, 56, 7682-7690.

Wild, D. Immunoassay for beginners. In The Immunoassay Handbook. Theory and Applications of Ligand Binding, ELISA and Related Techniques. Fourth Edition, 2013. Wild, D. (ed). Elsevier Ltd, Oxford, UK.

M. Javad, N. Mohammad, F. Borna, M. Gholamzad, M. Ramezani and K. Abnous, Biosens. Bioelectron., 2016, 86, $235-246$.

Sajid M., Kahde A. N., Daud M., J. Saudi Chem. Soc., 2015, 19, 689-705

E. Miró-Casas, M. Farré Albaladejo, M. I. Covas, J. O. Rodriguez, E. Menoyo Colomer, R. M. Lamuela Raventós and R. De La Torre, Anal. Biochem., 2001, 294, 63-72.

\section{B. P. Kearney, J. F. Flaherty and J. Shah, Clin. Pharmacokinet., 2004, 43, 595-612.}

M. Pyra, P. L. Anderson, C. W. Hendrix, R. Heffron, K. Mugwanya, J. E. Haberer, K. K. Thomas, C. Celum, D. Donnell, M. A. Marzinke, E. A. Bukusi, N. R. Mugo, S. Asiimwe, E. Katabira and J. M. Baeten, Aids, 2018, 32, 1891-1898.

L. Anfossi, F. Di Nardo, A. Russo, S. Cavalera, C. Giovannoli, G. Spano, S. Baumgartner, K. Lauter and C. Baggiani, Anal. Bioanal. Chem., 2019, 411, 1905-1913.

Y. R. Guo, S. Y. Liu, W. J. Gui and G. N. Zhu, Anal. Biochem., 2009, 389, 32-39.

F. Di Nardo, C. Baggiani, C. Giovannoli, G. Spano and L. Anfossi, Microchim. Acta, 2017, 184, 1295-1304.

F. Di Nardo, L. Anfossi, L. Ozella, A. Saccani, C. Giovannoli, G. Spano and C. Baggiani, J. Chromatogr. B, 2016, 1028, 192198.

L. Lalley-Chareczko, E. Hiserodt, G. Moorthy, A. Zuppa, K. Mounzer and H. Koenig, Front. Pharmacol., 2020, 11, 286. 


\section{Electronic Supplementary Information}

\section{Monoclonal antibodies with subnanomolar affinity to tenofovir for monitoring adherence to antiretroviral therapies: from hapten synthesis to prototype development}

Simone Cavalera ${ }^{a}$, Consuelo Agullób ${ }^{\text {, Josep V. Mercader }}{ }^{c}$, Fabio Di Nardo ${ }^{a}$, Matteo Chiarello ${ }^{a}$, Laura Anfossi ${ }^{\text {a }}$, Claudio Baggiani ${ }^{a}$, Antonio D'Avolio ${ }^{d}$, Antonio Abad-Somovilla ${ }^{b}$, and Antonio Abad-Fuentes* ${ }^{c}$

\section{Characterization of TFV Derivatives}

The progress of reactions was followed by thin-layer chromatography (TLC), using aluminum plates coated with silica gel (60F245 Merck). TLC plates were visualized by exposure to short wave ultraviolet light (254 $\mathrm{nm}$ ) and irreversibly stained by treatment with an aqueous solution of ceric ammonium molybdate followed by heating. Purification of the synthesized compounds was achieved with a Merck silica gel 60 flash chromatography column (230-400 mesh), using the mobile phase solvent mixture indicated. ${ }^{1} \mathrm{H}$ and ${ }^{13} \mathrm{C}$ NMR spectra were recorded on a Bruker Avance DRX-300 MHz, in the solvent indicated, at $300 \mathrm{MHz}$ and $75 \mathrm{MHz}$, respectively. ${ }^{31} \mathrm{P}$-NMR spectra were recorded under high-power proton decoupling conditions. The abbreviation used for NMR data are as follows: $s=$ singlet, $d=$ doublet, $t=$ triplet, $d d=$ double doublet, $b r=$ broad, $m=$ multiplet, Pur = purine ring. High resolution mass spectra (HRMS) were obtained by electrospray ionization (ESI) mode in a TripleTOF TM 5600 LC/MS/MS System (ABSciex, Framingham, MA, USA) mass spectrometer equipped with an electrospray source (Waters, Manchester, United Kingdom). The obtained data are expressed as mass/charge ratio $(\mathrm{m} / \mathrm{z})$.

\section{MALDI Mass Spectrometry Analysis of Bioconjugates}

Sample preparation.

A $100 \mu \mathrm{L}$ aliquot of protein conjugates purified by size-exclusion chromatography was dialyzed against Milli$\mathrm{Q}$ water for $24 \mathrm{~h}$. One microliter of every sample solution, containing about $1 \mu \mathrm{g} / \mu \mathrm{L}$ of protein conjugate, was spotted onto the MALDI plate, after the droplets were air-dried at room temperature, $1 \mu \mathrm{L}$ of matrix [10 $\mathrm{mg} / \mathrm{mL}$ sinapinic acid (Bruker) in $\left.70 \% \mathrm{CH}_{3} \mathrm{CN}, 0.1 \% \mathrm{CF}_{3} \mathrm{CO}_{2} \mathrm{H}\right]$ was added and allowed to air-dry at room temperature.

Mass spectrometry analysis.

The resulting mixtures were analyzed in a 5800 MALDI TOFTOF (ABSciex) in positive linear mode. Previously, the plate and the acquisition method were calibrated with $1 \mu \mathrm{L}$ of the TOF-TOF calibration mixture (ABSciex), in 13 positions. Every sample was calibrated by 'close external calibration' method with a BSA, OVA or HRP spectrum acquired in a close position. 


\section{NMR Spectroscopic Characterization of TFV $h$ and Intermediates}

Spectroscopic characterization data of methyl ester $\mathbf{1}$.

${ }^{1} \mathrm{H}$ NMR $\left(300 \mathrm{MHz}, \mathrm{CD}_{3} \mathrm{OD}\right) \delta 8.29$ (1H, s, H-2 Pur), 8.20 (1H, s, H-8 Pur), 4.37 (1H, dd, J=14.4, 3.2 Hz, $\left.\mathrm{H}_{\mathrm{a}}-1^{\prime \prime}\right), 4.22\left(1 \mathrm{H}, \mathrm{dd}, J=14.4,6.8 \mathrm{~Hz}, \mathrm{H}_{\mathrm{b}}-1\right.$ '), $3.91\left(1 \mathrm{H}, \mathrm{m}, \mathrm{H}-2\right.$ "), 3.79-3.67 (2H, m, $\left.\mathrm{H}_{2}-5\right), 3.71(1 \mathrm{H}, \mathrm{dd}, J=$ 12.8, $\left.9.6 \mathrm{~Hz}, \mathrm{H}_{\mathrm{a}}-1^{\prime}\right), 3.62\left(3 \mathrm{H}, \mathrm{s}, \mathrm{OCH}_{3}\right), 3.45\left(1 \mathrm{H}, \mathrm{dd}, J=12.8,10.2 \mathrm{~Hz}, \mathrm{H}_{\mathrm{b}}-1^{\prime}\right), 2.30\left(2 \mathrm{H}, \mathrm{t}, J=7.3 \mathrm{~Hz}, \mathrm{H}_{2}-2\right)$, 1.66-1.47 (4H, m, Hz- $\left.\mathrm{H}_{2}-3, \mathrm{H}_{2}-4\right), 1.17\left(3 \mathrm{H}, \mathrm{d}, J=6.2 \mathrm{~Hz}, \mathrm{H}_{3}-3\right.$ "); ${ }^{13} \mathrm{C}$ NMR (75 MHz, CD $\mathrm{CD}_{3} \delta 175.7(\mathrm{C}-1)$, 157.2 (C-6 Pur), 153.6 (C-2 Pur), 150.9 (C-4 Pur), 144,2 (C-8 Pur), 119.6 (C-5 Pur), 76.9 (d, J = $13.1 \mathrm{~Hz}$, C-2"), 66.5 (d, $J=160.3 \mathrm{~Hz}, \mathrm{C}-1$ '), 65.3 (d, $J=5.9 \mathrm{~Hz}, \mathrm{C}-5), 51.9\left(\mathrm{OCH}_{3}\right), 49.1$ (C-1"), 34.4 (C-2), 31.4 (d, J $=6.6 \mathrm{~Hz}, \mathrm{C}-4), 22.4$ (C-3), 16.8 (C-3"); ${ }^{31} \mathrm{P}$ NMR (121 MHz, CD $\left.3 \mathrm{OD}\right) \delta$ 15.75; HRMS calculated for $\mathrm{C}_{15} \mathrm{H}_{25} \mathrm{~N}_{5} \mathrm{O}_{6} \mathrm{P}[\mathrm{M}+\mathrm{H}]^{+}$402.1537, found 402.1525 .

\section{Spectroscopic characterization data of dimethyl diester 2.}

${ }^{1} \mathrm{H}$ NMR (300 MHz, CDCl $)_{3}$ ) 8.29 (1H, s, H-2 Pur), $7.92\left(1 \mathrm{H}, \mathrm{s}, \mathrm{H}-8\right.$ Pur), $6.19\left(2 \mathrm{H}, \mathrm{br} \mathrm{s}, \mathrm{NH}_{2}\right), 4.32$ (1H, dd, $J=14.4,3.0 \mathrm{~Hz}, \mathrm{H}_{\mathrm{a}}-1$ "), 4.09 (1H, dd, $J=14.4,7.8 \mathrm{~Hz}, \mathrm{H}_{\mathrm{b}}-1$ "), 4.03-3.87 (5H, m, 2H $\mathrm{H}_{2}-5, \mathrm{H}-2$ "), 3.82 (1H, dd, $\left.J=13.6,9.1 \mathrm{~Hz}, \mathrm{H}_{\mathrm{a}}-1^{\prime}\right), 3.62$ and $3.61\left(3 \mathrm{H}\right.$ each, each $\left.\mathrm{s}, 2 \mathrm{xOCH}_{3}\right), 3.55\left(1 \mathrm{H}, \mathrm{dd}, J=13.6,9.7 \mathrm{~Hz}, \mathrm{H}_{\mathrm{b}}-1^{\prime}\right)$, 2.31 and $2.28\left(2 \mathrm{H}\right.$ each, each $\left.\mathrm{t}, J=6.9 \mathrm{~Hz}, 2 \mathrm{xH}_{2}-2\right), 1.70-1.55\left(8 \mathrm{H}, \mathrm{m}, 2 \mathrm{xH}_{2}-3,2 \mathrm{xH}_{2}-4\right), 1.20(3 \mathrm{H}, \mathrm{d}, J=6.2$ $\mathrm{Hz}, \mathrm{H}_{3}-3$ "); ${ }^{13} \mathrm{C}$ NMR (75 MHz, $\mathrm{CDCl}_{3}$ ) $\delta 173.7$ (C-1), 155.7 (C-6 Pur), 152.9 (C-2 Pur), 150.1 (C-4 Pur), 141.8 (C-8 Pur), 119.2 (C-5 Pur), 76.4 (d, $J=12.3 \mathrm{~Hz}, \mathrm{C}-2$ "), 65.9 and 65.8 (two d, $J=5.3 \mathrm{~Hz}, 2 \times C-5$ ), 62.6 (d, $J=168.4 \mathrm{~Hz}, \mathrm{C}-1$ '), $51.6\left(2 \times \mathrm{XCH}_{3}\right), 48.2$ (C-1"), 33.4 and $33.3(2 \times C-2), 29.9$ and 29.8 (two d, $J=5.9 \mathrm{~Hz}$, 2xC-4), 21.0 and 20.9 (2xC-3), 16.5 (C-3"); ${ }^{31} \mathrm{P}$ NMR (121 MHz, $\mathrm{CDCl}_{3}$ ) $\delta 21.02$; HRMS calcd for $\mathrm{C}_{21} \mathrm{H}_{35} \mathrm{~N}_{5} \mathrm{O}_{8} \mathrm{P}[\mathrm{M}+\mathrm{H}]^{+}$516.2218, found 516.2209.

\section{Spectroscopic characterization data of TFVh.}

${ }^{1} \mathrm{H}$ NMR (300 MHz, CD $\left.{ }_{3} \mathrm{OD}\right) \delta 8.43(1 \mathrm{H}, \mathrm{s}, \mathrm{H}-2$ Pur), $8.36(1 \mathrm{H}, \mathrm{s}, \mathrm{H}-8 \mathrm{Pur}), 4.48(1 \mathrm{H}, \mathrm{dd}, J=14.4$, 3.1, $\mathrm{H}_{\mathrm{a}}-1$ ') $4.30\left(1 \mathrm{H}, \mathrm{dd}, J=14.4,7.0 \mathrm{~Hz}, \mathrm{H}_{\mathrm{b}}-1\right.$ '), $4.00(1 \mathrm{H}, \mathrm{dt}, J=6.6,3.0 \mathrm{~Hz}, \mathrm{H}-2$ '), $3.87(2 \mathrm{H}, \mathrm{dt}$, 5.6, 5.6 Hz Hz $\left.\mathrm{H}_{2}-5\right)$, $3.82\left(1 \mathrm{H}, J=13.1,9.3 \mathrm{~Hz}, \mathrm{H}_{\mathrm{a}}-1^{\prime}\right), 3.62\left(1 \mathrm{H}, \mathrm{dd}, J=13.1,9.8 \mathrm{~Hz}, \mathrm{H}_{\mathrm{b}}-1^{\prime}\right), 2.30(2 \mathrm{H}$, t, $\left.J=7.1 \mathrm{~Hz}, \mathrm{H}_{2}-2\right), 1.68-1.56\left(4 \mathrm{H}, \mathrm{m}, \mathrm{H}_{2}-3, \mathrm{H}_{2}-4\right), 1.21\left(3 \mathrm{H}, \mathrm{d}, J=6.2 \mathrm{~Hz}, \mathrm{H}_{3}-3{ }^{\prime \prime}\right) ;{ }^{13} \mathrm{C}$ NMR $(75$ $\mathrm{MHz}, \mathrm{CD}_{3} \mathrm{OD}$ ) $\delta 177.2$ (C-1), 152.0 (C-6 Pur), 150.5 (C-4 Pur), 146.5 (C-2 Pur), 145.7 (C-8 Pur), 119.2 (C-5 Pur), 76.9 (d, $J=12.6 \mathrm{~Hz}, \mathrm{C}-2$ "), 66.0 (d, $J=5.9 \mathrm{~Hz}, \mathrm{C}-5$ ), 64.6 (d, $J=162.1 \mathrm{~Hz}, \mathrm{C}-1^{\prime}$ ), 49.4 (C-1"), 34.4 (C-2), 31.2 (d, J = 6.2 Hz, C-4), 22.4 (C-3), 16.9 (C-3"); ${ }^{31} \mathrm{P}$ NMR (121 MHz, $\left.\mathrm{CD}_{3} \mathrm{OD}\right) \delta$ 17.51; HRMS calcd for $\mathrm{C}_{14} \mathrm{H}_{23} \mathrm{~N}_{5} \mathrm{O}_{6} \mathrm{P}[\mathrm{M}+\mathrm{H}]^{+} 388.1380$, found 388.1371 . 
${ }^{1} \mathrm{H}$ NMR spectrum of ester $\mathbf{1}\left(300 \mathrm{MHz}, \mathrm{CD}_{3} \mathrm{OD}\right)$

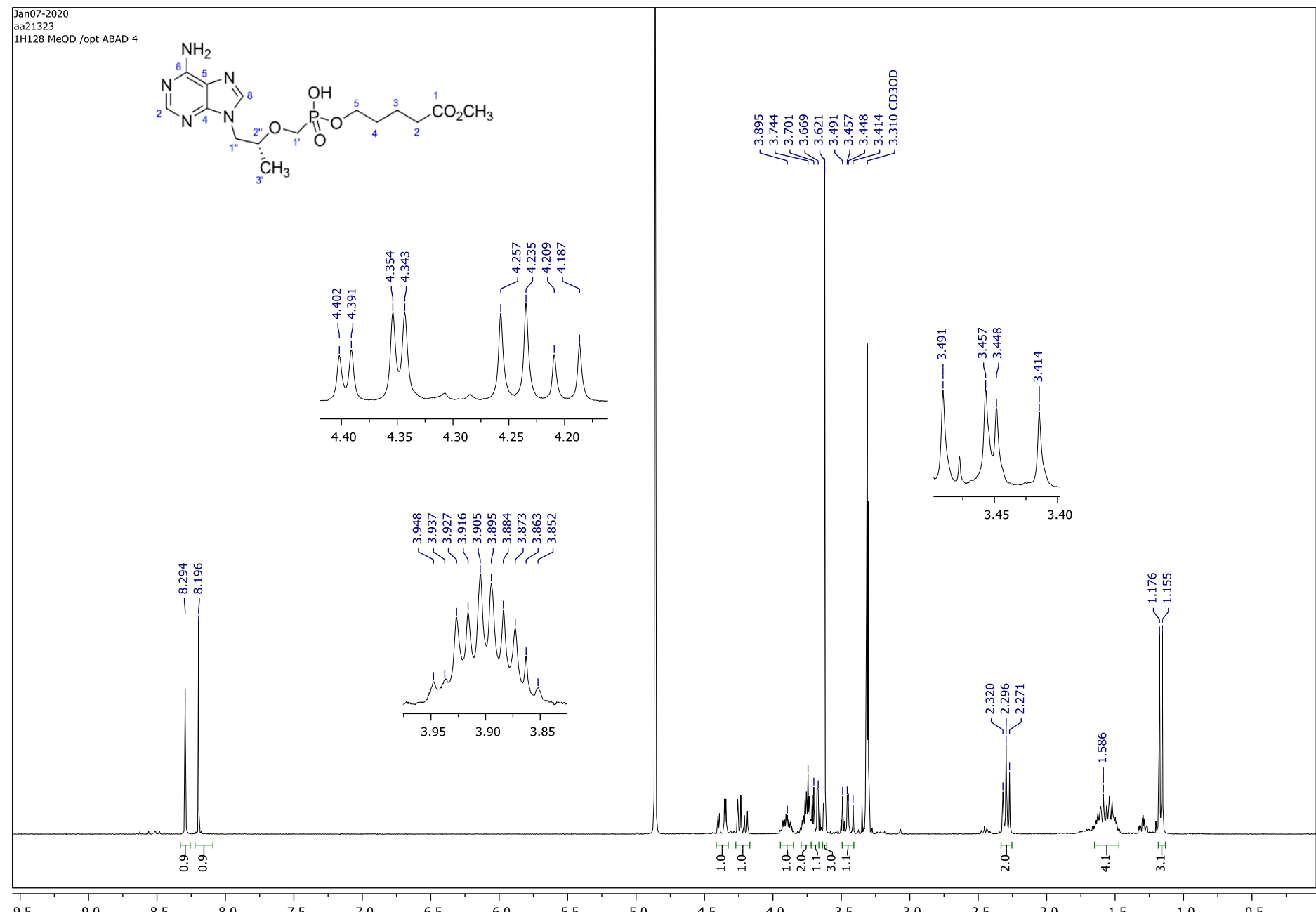


${ }^{13} \mathrm{C}$ NMR spectrum of ester $\mathbf{1}\left(75 \mathrm{MHz}, \mathrm{CD}_{3} \mathrm{OD}\right)$

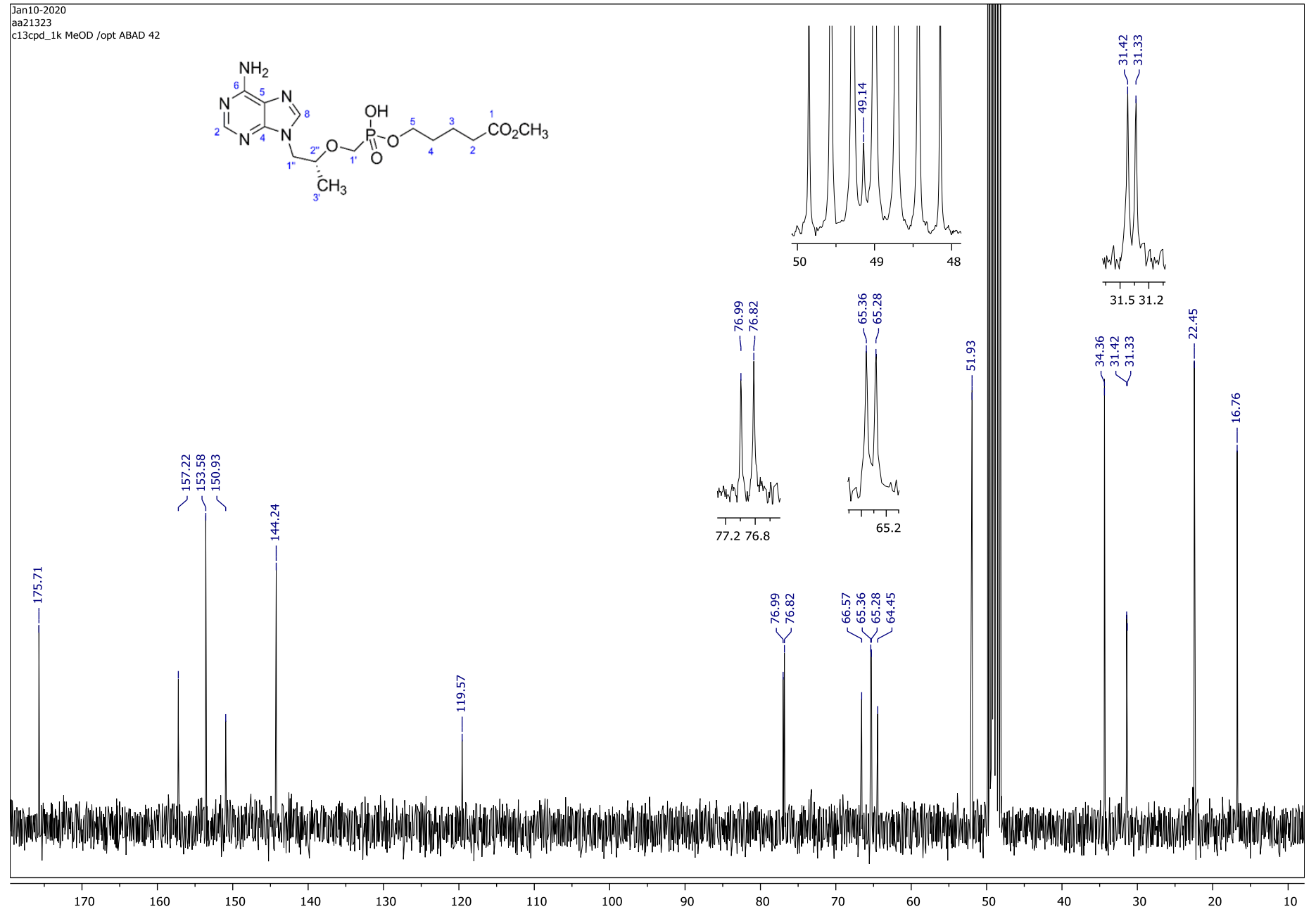


${ }^{1} \mathrm{H}$ NMR spectrum of diester $2\left(300 \mathrm{MHz}, \mathrm{CDCl}_{3}\right)$

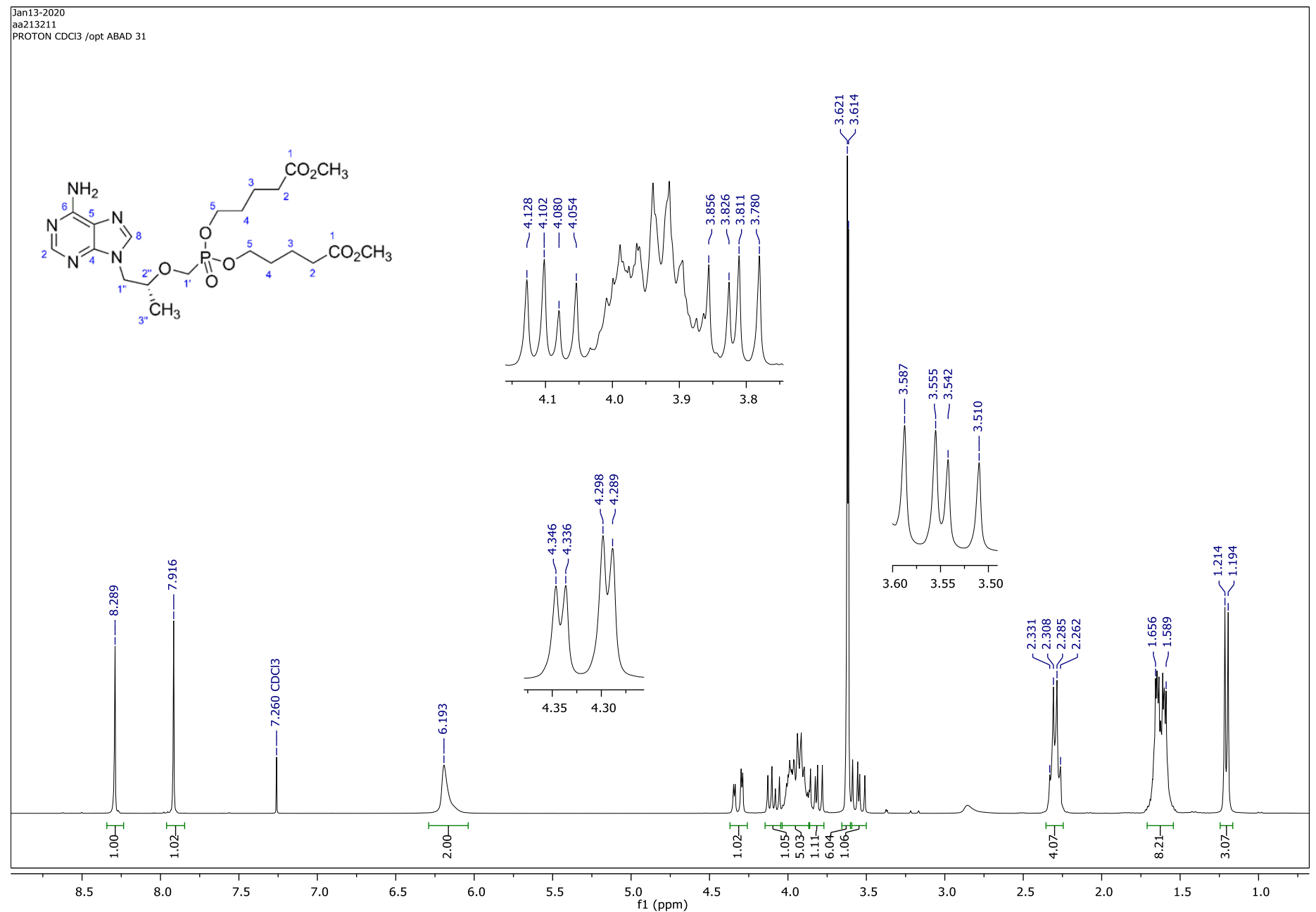


${ }^{13} \mathrm{C}$ NMR spectrum of diester $2\left(75 \mathrm{MHz}, \mathrm{CDCl}_{3}\right)$

Nov22-2018.130.1.1r

aa21107
c13cpdc CDCI3 /opt ABAD 34

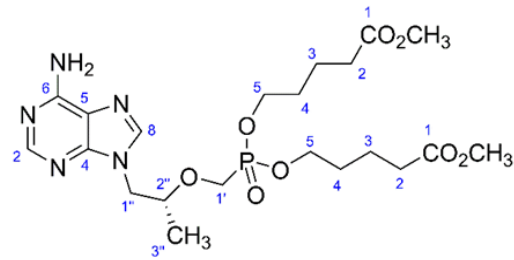

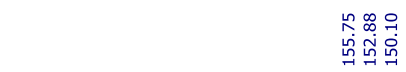

${ }_{3}{ }^{\circ} \mathrm{CH}_{3}$
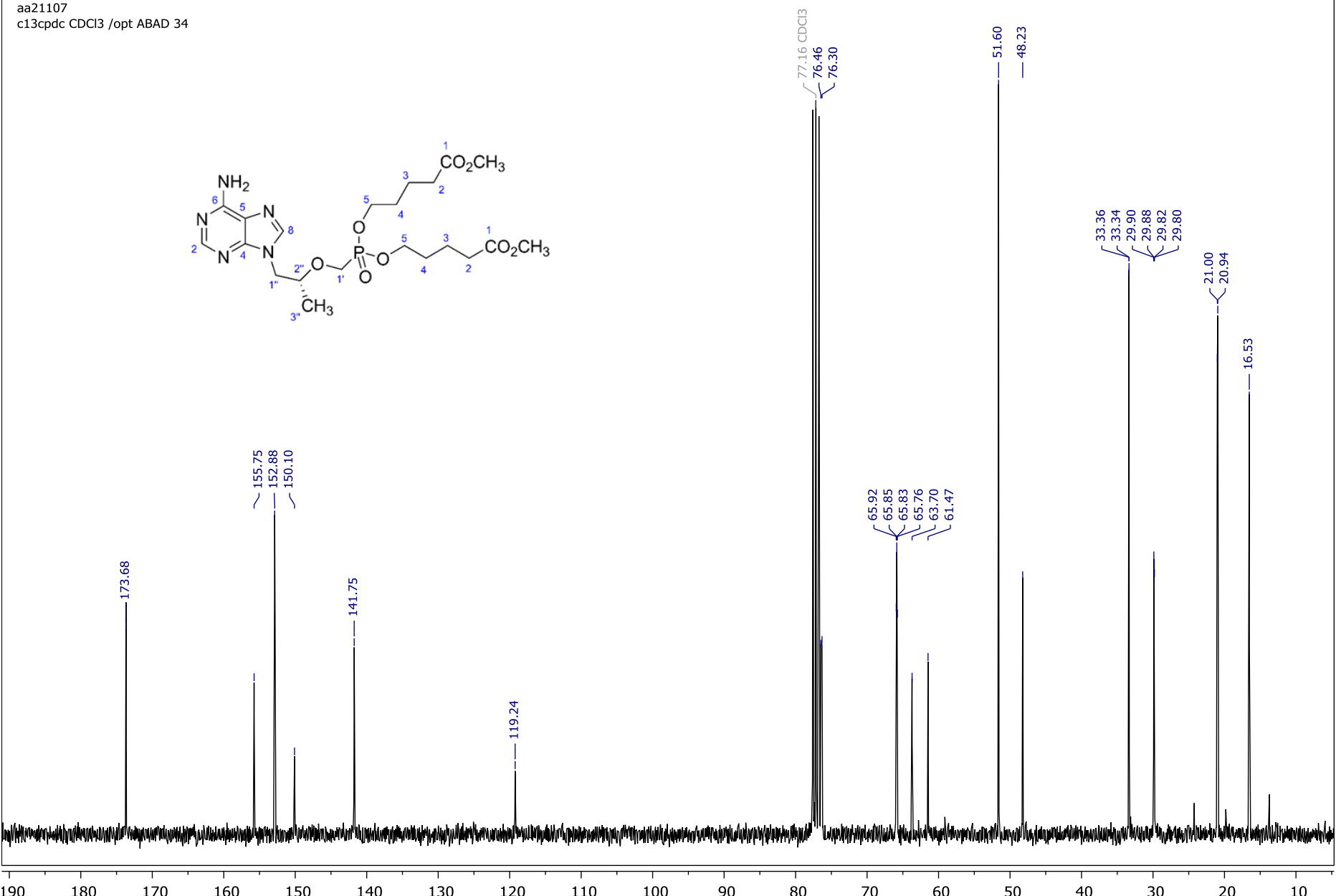

รั

$\stackrel{-1}{9}$

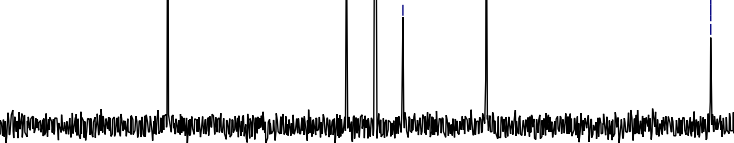

$190 \quad 180$

$\begin{array}{lll}170 & 160 & 150\end{array}$

140

$130 \quad 120$

80

50

20 
${ }^{1} \mathrm{H}$ NMR spectrum of TFV $\boldsymbol{h}\left(300 \mathrm{MHz}, \mathrm{CD}_{3} \mathrm{OD}\right)$

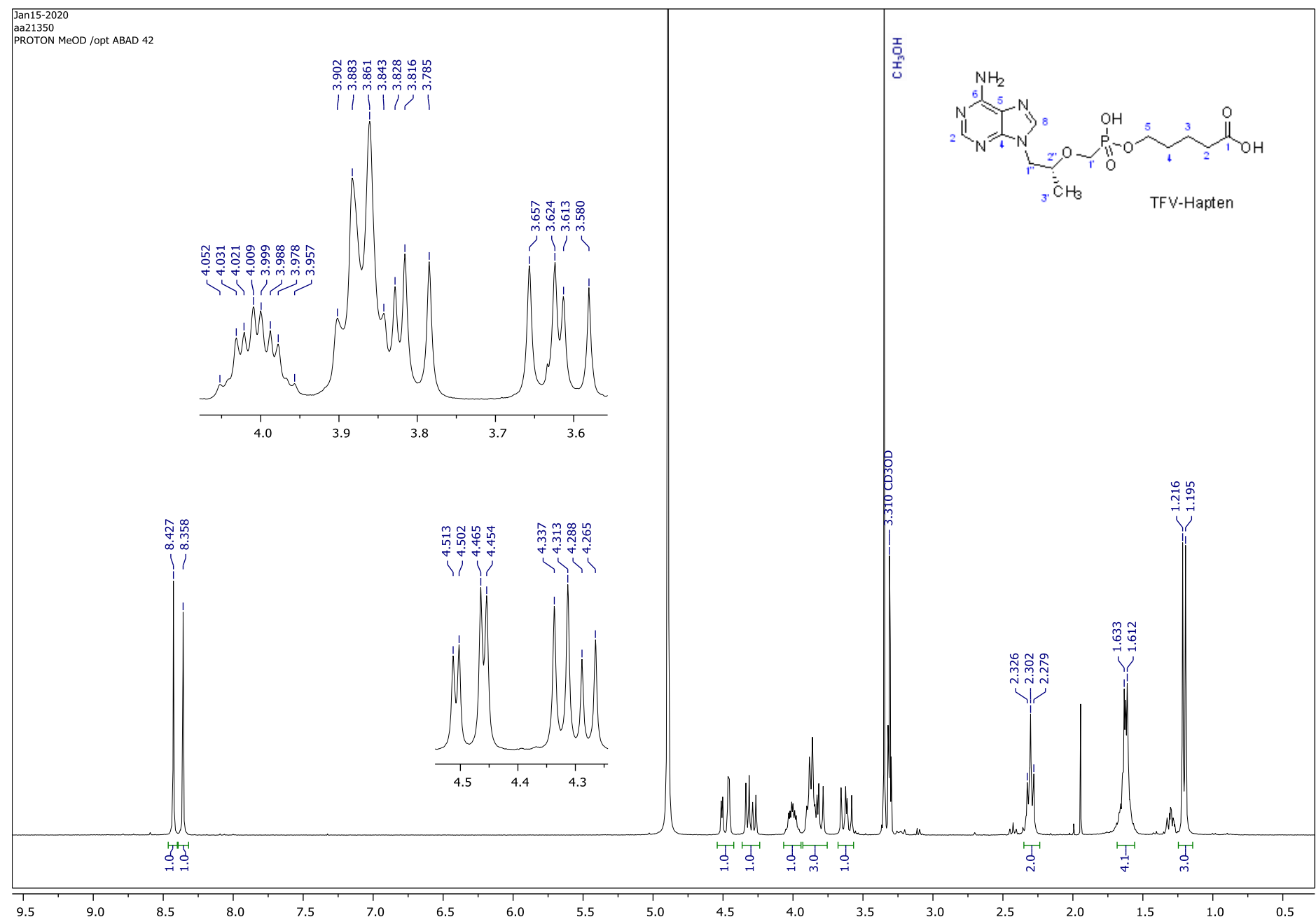


${ }^{13} \mathrm{C}$ NMR spectrum of TFVh $\left(75 \mathrm{MHz}, \mathrm{CD}_{3} \mathrm{OD}\right)$

$\operatorname{Jan} 15-2020$
aa21350

c13cpd_4k MeOD /opt ABAD 42
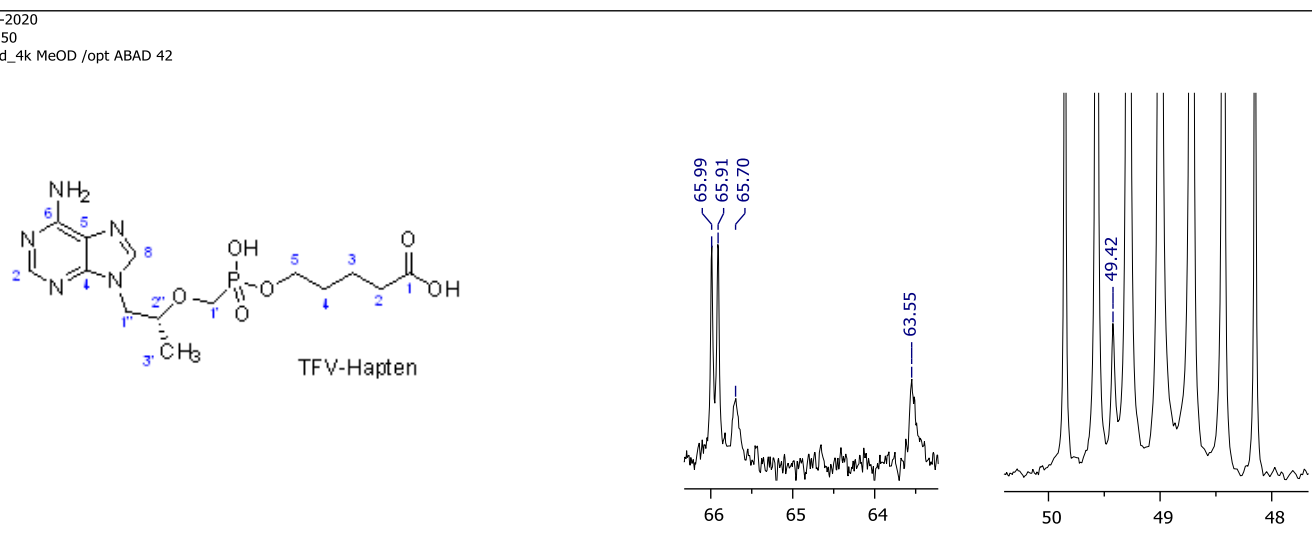

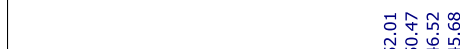

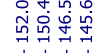
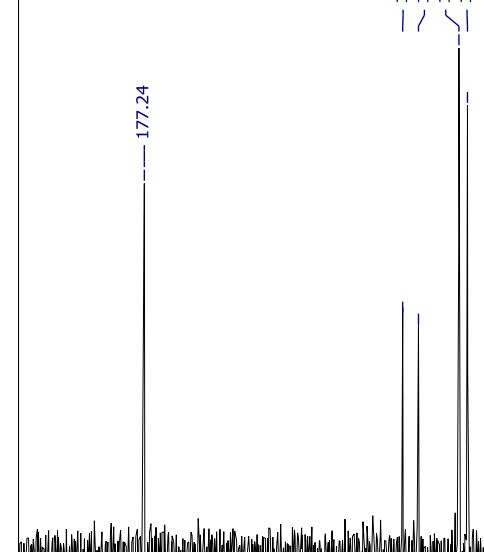

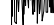

$180+170$
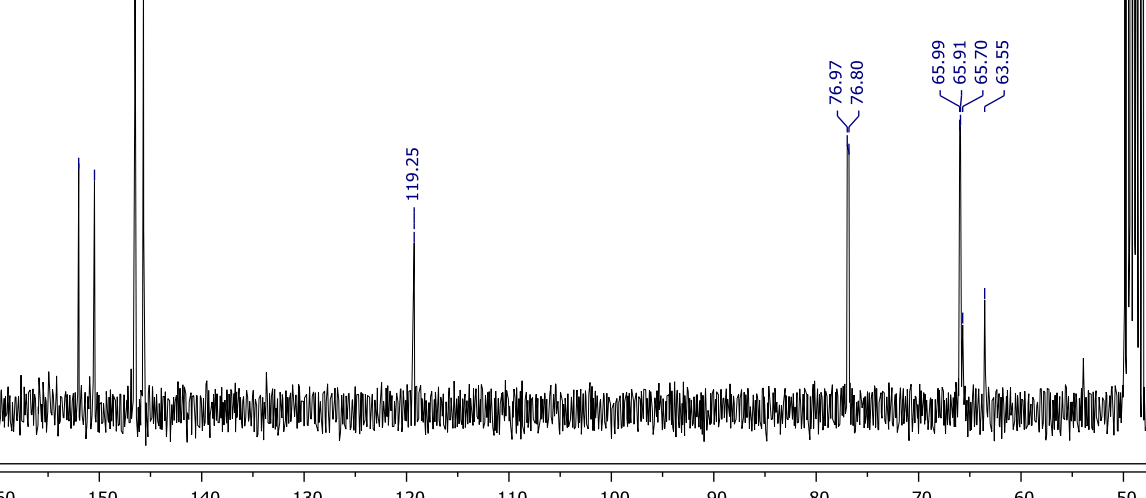

1 160

r. 1

$1301+1$

180

$+\quad 70$

$2+50$

40

30 
Edited HSQC NMR spectrum of TFV $\boldsymbol{h}\left(75 \mathrm{MHz}, \mathrm{CD}_{3} \mathrm{OD}\right)$

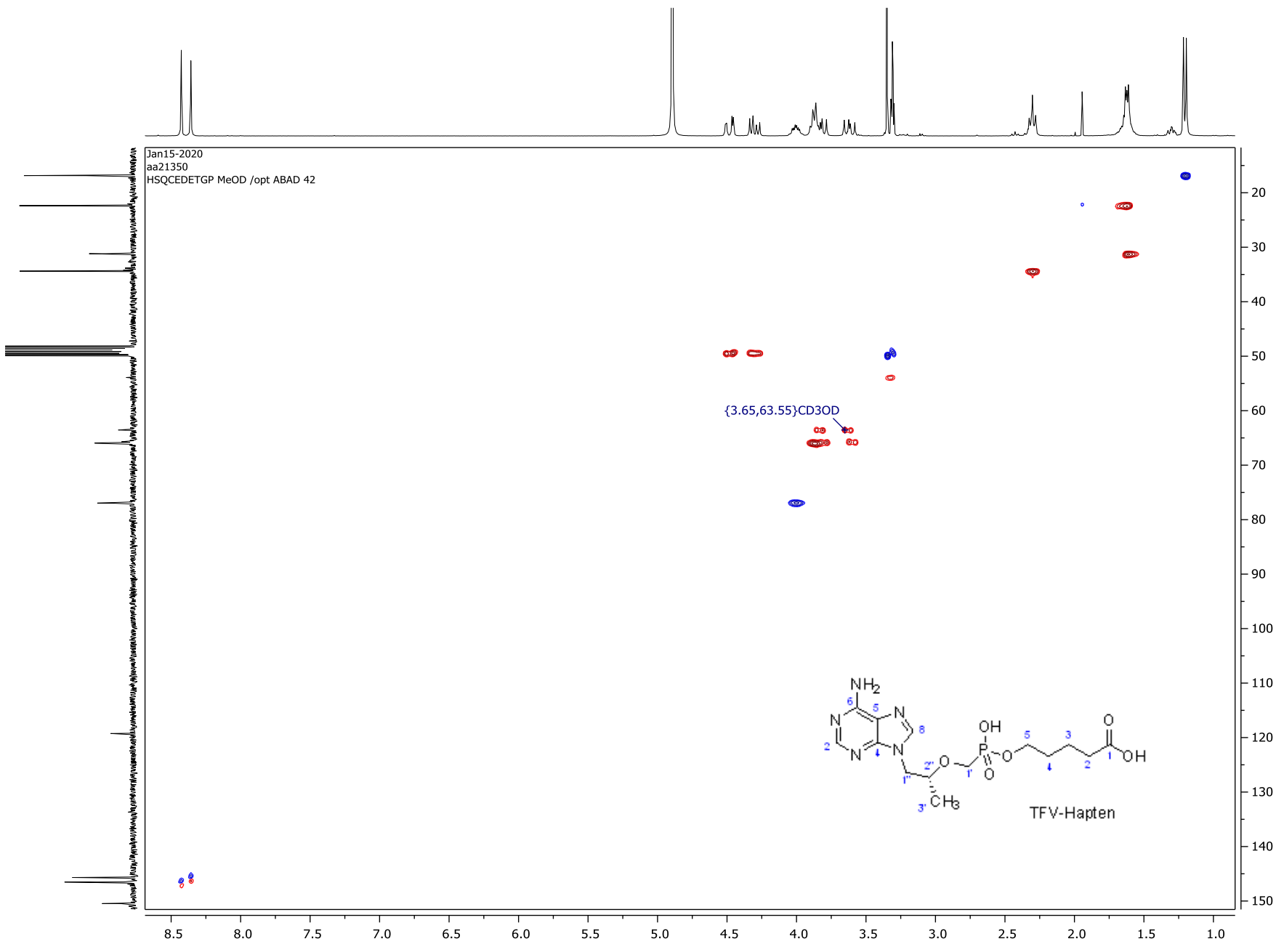




\section{ARTICLE}

Results of the experiments are shown in Figure S1.

\section{Lateral Flow Strip Production}

A 300-mm long nitrocellulose membrane was dispensed with immunoreagents using a XZ1010 Dispense Platform (BioDot, Irvine, CA, USA) dispenser at 0.5 $\mu \mathrm{L} / \mathrm{cm}$. The test line comprised BSA-TFVh conjugate (1 $\mathrm{mg} / \mathrm{mL}$ ), whereas the control line was drawn by dispensing GAM solution (1 mg/mL). Both reagents were diluted in PBS for dispensing. The membrane was dried at rt before assembling. The LFIA strips were assembled by sequentially pasting the dry nitrocellulose membrane, the sample pad, and the adsorbent pad on a backing support. Then, the membrane was cut into 4$\mathrm{mm}$ width strips using a CM5000 Guillotine Cutter (BioDot, Irvine, CA, USA) and stored sealed in dry tubes at $4{ }^{\circ} \mathrm{C}$. Signal from lateral flow assays was read using an EPSON Perfection V39 ultra-compact color image scanner from Seiko Epson Corp. (Suwa, Japan).

\section{Effect of ionic strength and $\mathrm{pH}$ on the binding and} sensitivity of MAbs \#13, \#321, and \#322

Calibration curves in ic competitive ELISA were prepared by diluting TFV and the mAb in buffers with different composition. In details, the reference buffer comprises $20 \mathrm{mM}$ phosphate byffer, $\mathrm{pH}$ 7.4, with 130 $\mathrm{mM} \mathrm{NaCl}$ added, the low and high ionic strenght buffers were obtained by adding 0 and $230 \mathrm{mM}$ of $\mathrm{NaCl}$ rather than 130 , while acid and basic conditions were obtained by adjusting the $\mathrm{pH}$ to 6.5 and 8.5 , respectively.

All other experimental details were kept as described.

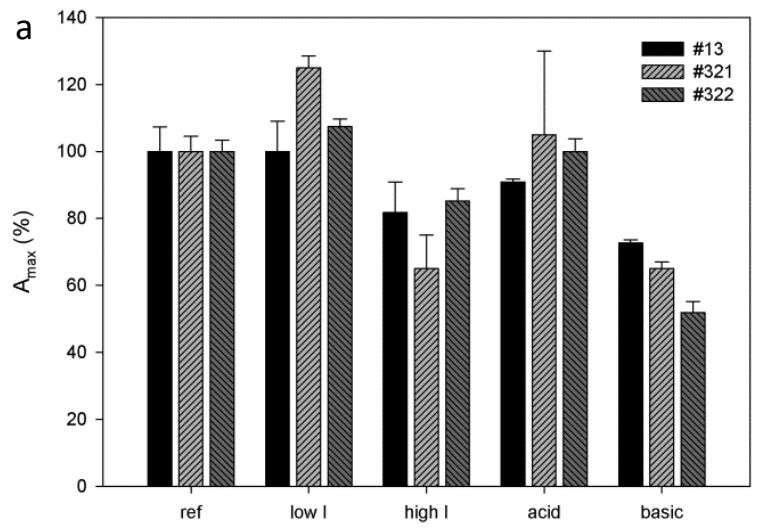

b

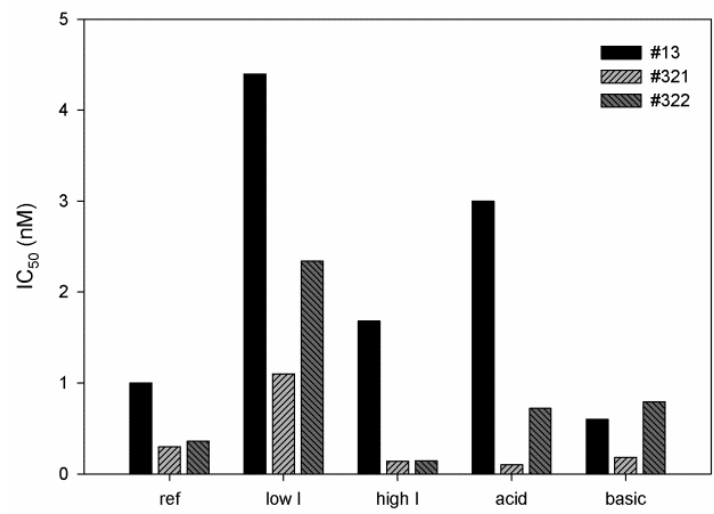

Figure S1: Effect of salt amount (low I and high I represent 0 and $230 \mathrm{mM}$ of $\mathrm{NaCl}$ added to the phosphate buffer) and $\mathrm{pH}$ (acid and basic correspond to 6.5 and 8.5, respectively) on the binding to the antigen and on the assay sensitivity, as measured by $A_{\max }$ variation (a) and $\mathrm{IC}_{50}$ value (b). The reference buffer (ref) was composed as follows: $20 \mathrm{mM}$ phosphate, $\mathrm{pH}$ 7.4 , with $130 \mathrm{mM}$ of $\mathrm{NaCl}$ added. 
